\title{
The Surgeon General's Call to Action To Promote Healthy Homes
}

\section{9}

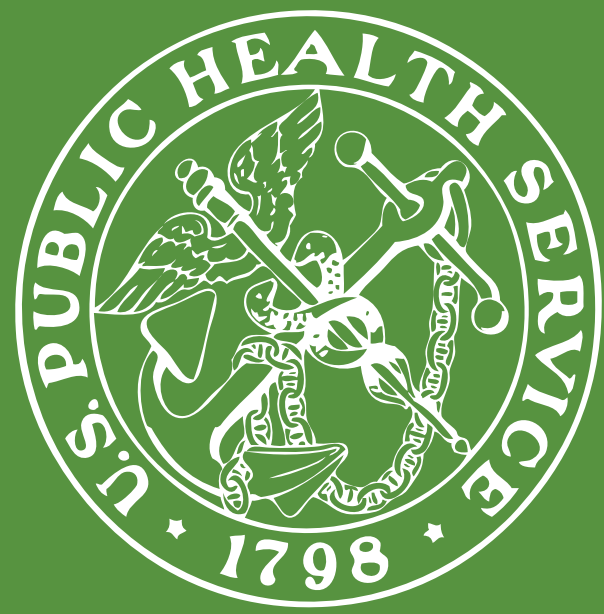

U.S. Department of Health and Human Services 



\section{The Surgeon General's Call to Action To Promote Healthy Homes}

\section{9}

A healthy home is sited, designed, built, renovated, and maintained in ways that support the health of residents.

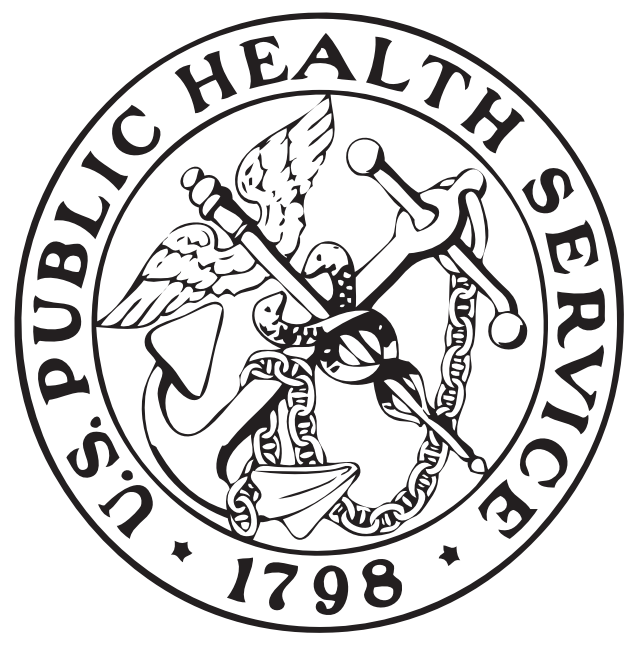




\section{U.S. DEPARTMENT OF HEALTH AND HUMAN SERVICES}

Public Health Service

Office Of The Surgeon General

This publication is available at http://www.surgeongeneral.gov

Suggested Citation

U.S. Department of Health and Human Services. The Surgeon General's Call to Action To Promote Healthy Homes. U.S. Department of Health and Human Services, Office of the Surgeon General, 2009. 


\section{Table of Contents}

Message from the Secretary,

U.S. Department of Health and Human Services .......................................

Foreword from the Acting Surgeon General,

U.S. Department of Health and Human Services .....................................vii

Section 1 The Need for Healthy Homes ................................................... 1

Section 2 The Connection Between Health and Homes ............................ 5

How Indoor Air Quality Affects Health ..............................................5

How Water Quality Affects Health .................................................. 8

How Residential Chemicals Affect Health .......................................9

How Housing Structure and Design Affect Health ............................10

Elevated Lead Levels ........................................................................ 13

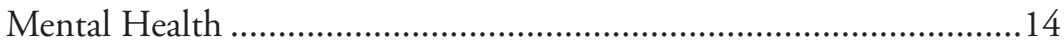

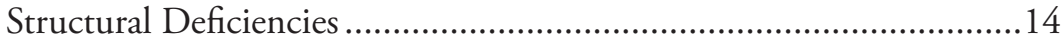

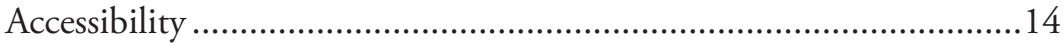

How Behaviors Contribute to Adverse Health Related to Homes ......15

Disparities in Access to Safe and Healthy Homes...............................15

Housing Instability and Homelessness ............................................ 18

Section 3 Promoting Healthy Homes through Prevention ....................... 19

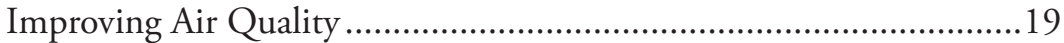

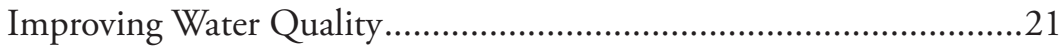

Reducing Harmful Chemicals........................................................22

Improving Housing Structure and Design ......................................22

Preventing Elevated Lead Levels....................................................24

Improving Mental Health ............................................................24

Remedying Structural Deficiencies................................................24

Improving Accessibility .............................................................25

Encouraging Safe and Healthy Behaviors .......................................22

Reducing Disparities in Access to Healthy and Safe Homes ..............25

Addressing Community Factors that Affect Health and Homes .........26

Housing Instability and Homelessness .............................................27 
Section 4 Homes and Health Research

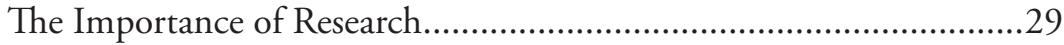

Research Methods....................................................................29

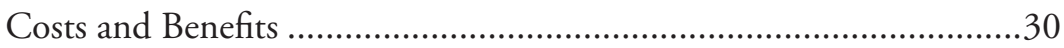

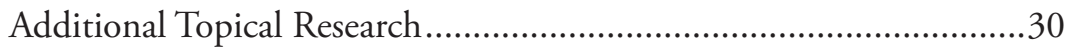

Section 5 Ensuring Healthy Homes: Taking Action for the Future ............33

Goal 1: Ensuring Healthy, Safe, Affordable, and Accessible Homes....33

Goal 2: Increase Public Awareness and Promote Health Literacy........39

Goal 3: Conduct Healthy Homes Research........................................40

Goal 4: Translate Research into Practice and Policy............................42

Section 6 Conclusions ..................................................................45

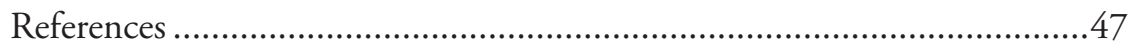

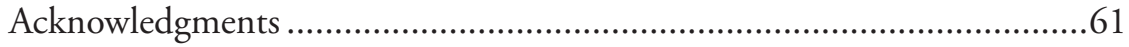

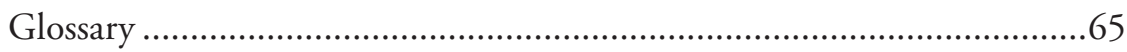




\section{Message from the Secretary, U.S. Department of Health and Human Services}

Houses have always been one of the centerpieces of American life. Houses are the places where parents raise their children, where family reunions take place, and where people live, work, and play. Americans have always realized that healthy houses can lead to healthier lives.

Many of the extraordinary improvements in health that were achieved in the $20^{\text {th }}$ century resulted from improvements in the Nation's homes. Although poorly maintained homes increases the risk for injury and illness, unhealthy and unsafe housing continues to affect the health of millions of people of all income levels, geographic areas, and walks of life in the United States.

That is why this Surgeon General's Call to Action To Promote Healthy Homes is so important.

The Call to Action describes the steps people can take now to protect themselves from disease, disability and injury that may result from health hazards in their houses. These steps have been scientifically proven to reduce health problems that cause or contribute to disease and injuries. And, improving literacy about healthy homes and teaching people about the steps they can take to change unhealthy and unsafe behaviors at home will lead to better health for all Americans.

This Call to Action also outlines the next steps of a society-wide, comprehensive and coordinated approach to healthy homes that will result in the greatest possible public health impact and reduce disparities in the availability of healthy, safe, affordable, accessible, and environmentally friendly homes.

As Secretary of the Department of Health and Human Services and as a wife, mother and homeowner concerned about the health of my family, I urge all Americans to embrace the holistic approach to creating healthy homes described in the Surgeon General's Call to Action To Promote Healthy Homes.

Kathleen Sebelius

Secretary

U.S. Department of Health and Human Services 
"The connection between the health and the dwelling of the population is one of the most important that exists."

\section{-Florence Nightingale}

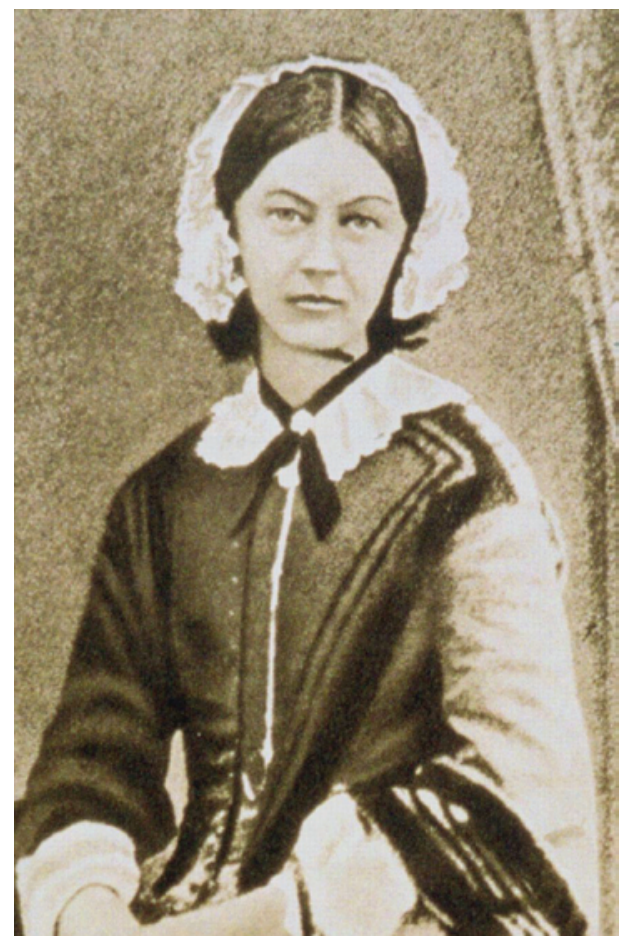

Portrait of Florence Nightingale the founder of the nursing profession. 


\section{Foreword from the Acting Surgeon General, U.S. Department of Health and Human Services}

Nightingale understood that health status is directly related to the home and consistently stressed that housing can cause or can contribute to numerous illnesses and injuries. In the United States today the leading preventable causes of death, disease, and disability are asthma, lead poisoning, deaths in house fires, falls on stairs and from windows, burns and scald injuries, and drowning in bathtubs and pools. Although residents of poorly maintained homes are at increased risk for injury and illness, no population group is immune to illness or injury occurring in houses. Design features of the house and how a house is linked to the surrounding neighborhood also affects health (Krieger and Higgins 2002).

A healthy home is sited, designed, built, renovated, and maintained in ways that support the health of residents. Specific features that constitute healthy housing include structural and safety aspects of the home (i.e., how the home is designed, constructed, and maintained; its physical characteristics; and the presence or absence of safety devices), quality of indoor air and water, and the presence or absence of chemicals. Individual resident behavior, such as installing and maintaining smoke alarms, implementing smoke-free rules, and controlling or eliminating hazards such as lead paint and radon gas also are important aspects of healthy and safe home environments. The surrounding neighborhood and community are also important aspects of healthy homes. Finally, homelessness, which is the worst case of lack of access to healthy housing, has dire health consequences.

I have issued The Surgeon General's Call to Action To Promote Healthy Homes to focus attention on the public health impact of housing and to begin a national dialogue on how we can promote healthy homes in the United States. This Call to Action presents an overview of issues that contribute to our nation's unhealthy housing. It also urges a dynamic and coordinated effort to improve housing factors that affect health and describes features that make a house and its surrounding property healthy. A series of mutually supportive and mutually necessary coordinated actions are outlined in this document. They call on people from many walks of life to join in a discussion about healthy homes issues; to make informed, shared, and compassionate decisions; and to develop imaginative and realistic solutions that will help ensure that safe, healthy, affordable, and accessible homes are available to everyone in the United States.

Steven K. Galson, M.D., M.P.H.

RADM, USPHS

Acting Surgeon General 


\section{Section 1}

\section{The Need for Healthy Homes}

The connection between housing and health is well established. As early as the mid- $19^{\text {th }}$ century, physicians advocated for decent housing as a strategy to reduce death and illness among the poor (Krieger and Higgins 2002; von Hoffman 1998). The typhoid and tuberculosis experiences showed that basic sanitation, ventilation, reduced household crowding, and other improvements in housing made a powerful contribution to conquering these epidemics. Furthermore, improved sanitation through indoor plumbing, the creation of smooth and cleanable interior surfaces, and better food preservation and storage facilities in homes were clearly linked to other advances in public health. Many modern homes and building codes trace their ancestry to the public health responses to epidemics that occurred with the rapid industrialization and urbanization in Western countries over a hundred years ago. In the mid- $20^{\text {th }}$ century, however, housing and health agencies became organizationally separated, resulting in a diminished focus on the prevention of housing-related disease and illness.

Recently, the public health community renewed its interest in promoting healthy homes. Multiple research studies have demonstrated improved health outcomes with policies targeting living conditions, especially homes. For example, lead poisoning prevention policies have greatly reduced childhood lead exposure in the United States (Centers for Disease Control and Prevention 2005a; Pirkle et al. 2006). Smoke alarm legislation has been demonstrated to increase working smoke alarm prevalence and to reduce fatal fires and fire deaths in a U.S. county (McLoughlin et al. 1985). These and many other successes highlight the health benefits of targeting interventions to reduce or eliminate health hazards in homes.

Many factors influence health and safety in homes, including structural and safety aspects of the home (i.e., how the home is designed, constructed, and maintained; its physical characteristics; and the presence or absence of safety devices); quality of indoor air; water quality; and chemicals; resident behavior; and the house's immediate surroundings. Such factors support or detract from the health of those who live there. Some common hazards that affect health and safety include house fires caused by smoking or electrical hazards, carbon monoxide from poorly vented combustion, poor lighting, lack of handrails on stairs, open upper-story windows, improperly stored firearms and poisonous substances, moisture intrusion, radon gas, and inadequate supervision of 
children around bathtubs and pools. Many hazards potentially affect everyone, regardless of socioeconomic status. Secondhand smoke, exposure to chemicals such as pesticides and some household cleaning products, allergens such as dust mites, fire and burn hazards, and fall hazards such as clutter and poor lighting can be found in many homes and in all neighborhoods. These hazards can result in a multitude of health effects, including poisonings, fire and fallrelated injuries, and lung diseases such as cancer and asthma (Matte and Jacobs 2000).

Some populations are disproportionately affected by health and housing issues. For people with disabilities, certain design elements and construction characteristics of homes, such as stairs or narrow doorways, can limit an entire range of housing options and adversely affect ease of access to and within the house. A home's design features can either exclude or enhance the ability of a person with disabilities to participate in the community. Appropriate housing design and construction, on the other hand, can allow the elderly to remain at home and function independently rather than move to an assisted living facility or nursing home. Residents of homes with significant upkeep problems and structural and safety defects, such as lack of specific safety devices, deferred maintenance, moisture, and pest infestation, are also at increased risk for housing-related illness, injury, and disability. Moreover, some hazards are more common in certain geographic locations. For example, radon gas levels and the potential for extreme weather conditions and disasters vary across the country (Committee on Health Risks of Exposure to Radiation [BEIR VI] 1999; World Meteorological Organization undated).

A comprehensive, coordinated approach to healthy homes will result in the greatest public health impact. Directing resources toward a single disease or condition rather than working to improve the overall housing environment is inefficient and does not address residents' health and safety risks holistically. Consequently, some practitioners and researchers have begun promoting a more comprehensive and coordinated approach to improving health and safety in homes (Jacobs et al. 2007; Sharfstein and Sandel 1998). Health care workers who visit homes also recognize that the residents they serve often face multiple health and safety issues. Because of economies of scale and more efficient use of human and other resources, a holistic approach can be less expensive than addressing problems individually (U.S. Department of Housing and Urban Development 2000). Finally, the holistic approach may enhance housing affordability both by reducing the costs associated with uncoordinated housing improvements and because one intervention may address two or more adverse health conditions. For example, repairs to deteriorated lead-based paint caused by a roof leak can be less expensive if the 
roof leak and the deteriorated paint repairs are coordinated; just repairing the paint without fixing the leak would be more expensive because deterioration would continue, leading to more repairs and increased costs over the long run. Repairing holes in floors may not only prevent falls but also reduce the possibility of pests entering the house.

In this Call to Action, the term homes includes not only the dwelling itself, but also the land immediately around the house and any other structures on the property. A healthy home is sited, designed, built, renovated, and maintained in ways that support the health of residents. Healthy houses can be single-family homes, apartments, townhomes, duplexes, condominiums, or manufactured homes.

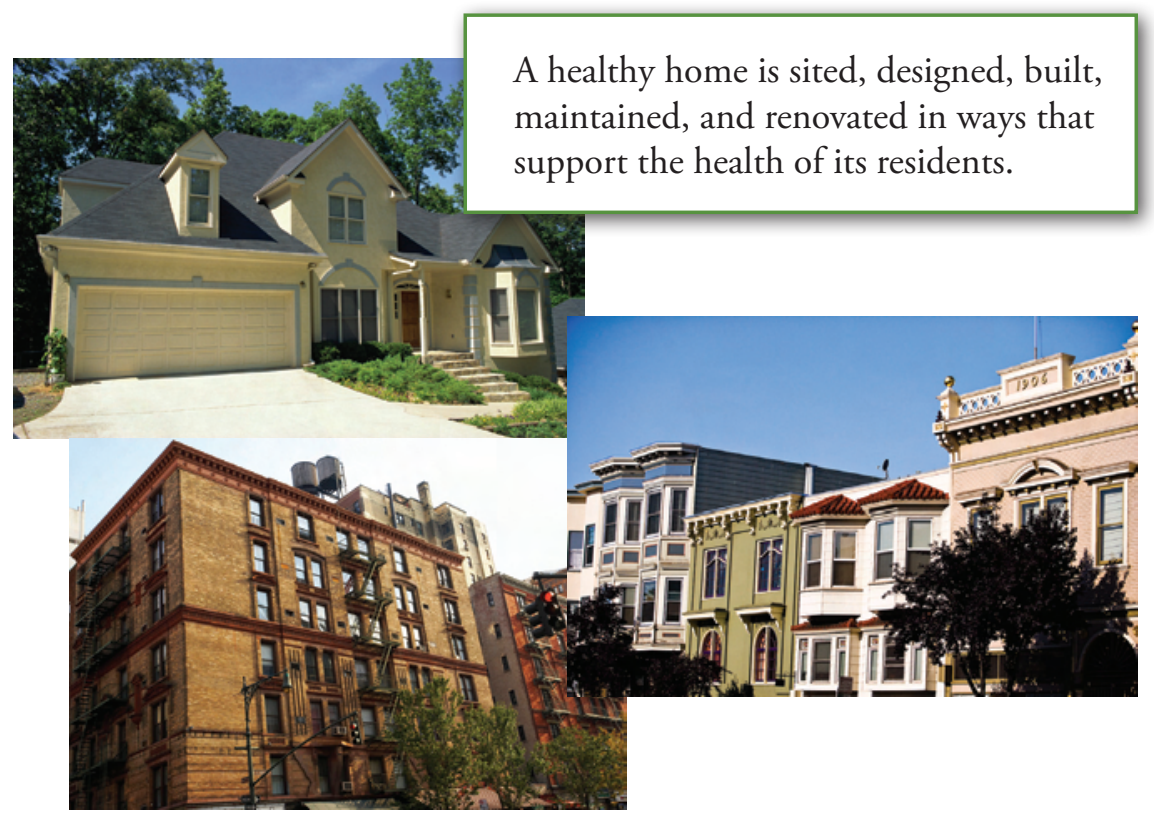

Three pictures of different types of houses: a single-family suburban house; a row of stucco townhouses; and a high-rise, multifamily apartment building.

The concept of healthy homes extends beyond the four walls of a dwelling to its surroundings - to the land immediately around the house, to adjacent structures and amenities (such as outbuildings, trees, and recreational equipment), and to the neighborhood setting. A house does not exist in isolation. Although the larger community context of a house is generally beyond the scope of this document, it is part of a larger community; the place from which people depart to work, play, study, and interact with others; and the place to which they return from these activities. Community 
factors including the ways people behave and relate to each other, the way the community is designed and built, and the state of the environment, contribute critically to healthy homes. Health-promoting features of the community may include sidewalks and bicycle trails; parks and green space; mass transit; and nearby destinations such as stores, schools, and workplaces. Many of these features are encompassed in the approach known as "smart growth" (Frumkin et al. 2004). In addition, the ways people behave and relate to each other are also essential to health.

This Call to Action also emphasizes the public health importance of ensuring the availability of safe, healthy, affordable, accessible, and environmentally friendly homes for the U.S. population. Additionally, it describes housingrelated health and safety issues for which interventions are available, as well as areas where further research and evaluation are needed. The costs and benefits of some interventions have been demonstrated; for these interventions the savings for both the medical and housing sectors can be substantial. The problems, consequences, and remedies for unhealthy housing are described in subsequent sections. 


\section{Section 2 \\ The Connection Between Health and Homes}

Many factors influence health and safety in homes, including structural and safety aspects of the home (i.e., how the home is designed, constructed, and maintained; its physical characteristics; and the presence or absence of safety devices); quality of indoor air; water quality; chemicals; resident behavior; and the house's immediate surroundings. The link between these housing features and illness and injury is clear and compelling. Homes' structural and safety features can increase risk for injuries, elevate blood lead levels, and exacerbate other conditions. Poor indoor air quality contributes to cancers, cardiovascular disease, asthma, and other illnesses. Poor water quality can lead to gastrointestinal illness and a range of other conditions, including neurological effects and cancer. Some chemicals in and around the home can contribute to acute poisonings and other toxic effects. All of these issues are influenced both by the physical environment of the home and by the behavior of the people living in the home.

\section{How Indoor Air Quality Affects Health}

Poor indoor air quality can contribute to symptoms ranging from eye, nose, and throat irritation to chronic conditions. Pollution sources such as wood smoke, natural gas combustion, or cigarette smoking that release gases or particles into the air can contribute to indoor air quality problems in homes. For example, secondhand smoke can cause respiratory and heart disease, whereas radon causes cancer. Inadequate ventilation also contributes to poor indoor air quality. High temperature and humidity levels can also increase concentrations of some pollutants. In addition, the use of candles, incense, or home deodorizers can increase symptoms in individuals with preexisting respiratory conditions (National Institute of Building Sciences 2005).

\section{Secondhand Smoke}

An estimated 38,112 lung cancer and heart disease deaths annually are attributed to exposure to secondhand smoke (Centers for Disease Control and Prevention 2005b). Secondhand smoke also contributes to respiratory diseases and other health problems. In 2000, more than 126 million U.S. residents ages 3 years and older were exposed to secondhand smoke; for 
most, the home was the primary site of exposure (U.S. Department of Health and Human Services 2006). The risk for exposure extends beyond the immediate family. Smokers living in multifamily residences (such as apartment and condominium complexes) can affect not only family members, but other residents as well.

\section{Carbon Monoxide}

Carbon monoxide is a colorless, odorless, poisonous waste gas produced when any fuel, such as gas, oil, kerosene, wood, or charcoal, is burned. Carbon monoxide exposure in the home can also result when electrical power to homes is interrupted for extended periods, such as after blizzards, ice storms, hurricanes, or tornadoes, and when residents without electrical power use generators or gas grills inside their homes. Carbon monoxide exposure is responsible for approximately 450 deaths and more than 15,000 emergency department visits annually; $64 \%$ of these exposures occurred in the home (Centers for Disease Control and Prevention 2005c). Acute exposure to high levels can cause unconsciousness, long-term neurological disabilities, coma, cardiorespiratory failure, and death (Ernst and Zibrak 1998). Chronic low-level exposure can cause viral-like symptoms such as fatigue, dizziness, headache, and disorientation (Centers for Disease Control and Prevention 2008; Raub et al. 2000). A large proportion of reported carbon monoxide exposures occur in the winter. Increased use of home heating systems; use of gasoline-powered generators during and after winter storms; and indoor use of charcoal grills, portable stoves, and space heaters have all reportedly contributed to the increase in carbon monoxide exposures during winter (Centers for Disease Control and Prevention 2005c; Daley et al. 2000). Nearly 60\% of unintentional carbon monoxide deaths occur in middle-aged and elderly adults, a population that may be particularly susceptible because of preexisting health conditions (Centers for Disease Control and Prevention 2007a).

\section{$\underline{\text { Radon Gas }}$}

Radon is a naturally occurring radioactive gas emitted by the normal decay of uranium, which is found in most soils; some soils have higher levels than others (Centers for Disease Control and Prevention and U.S. Department of Housing and Urban Development 2006). Radon is the leading cause of lung cancer among nonsmokers, causing an estimated 15,400-21,800 lung cancer deaths annually (Committee on Health Risks of Exposure to Radiation [BEIR VI] 1999; Frumkin and Samet 2001; U.S. Environmental Protection Agency 2003). Nearly one in 15 homes in the United States have 
radon levels above 4 picocuries per liter ( $\mathrm{pCi} / \mathrm{L}$ ), the level at which the U.S. Environmental Protection Agency (EPA) recommends taking specific steps to reduce radon levels in the home (U.S. Environmental Protection Agency undated a). Radon gas can enter the home through structural deficiencies such as gaps between basement walls or large cracks in the foundation, and its presence can be detected through a simple test (Field et al. 2000). A house in an upper Midwest or Eastern state, for example, is more likely to have an elevated level of radon compared with a house in the South or on the West Coast (U.S. Environmental Protection Agency undated b). A study in one Midwestern state found that radon levels in $60 \%$ of the houses tested exceeded the EPA's action level of 4 pCi/L (Field et al. 2000).

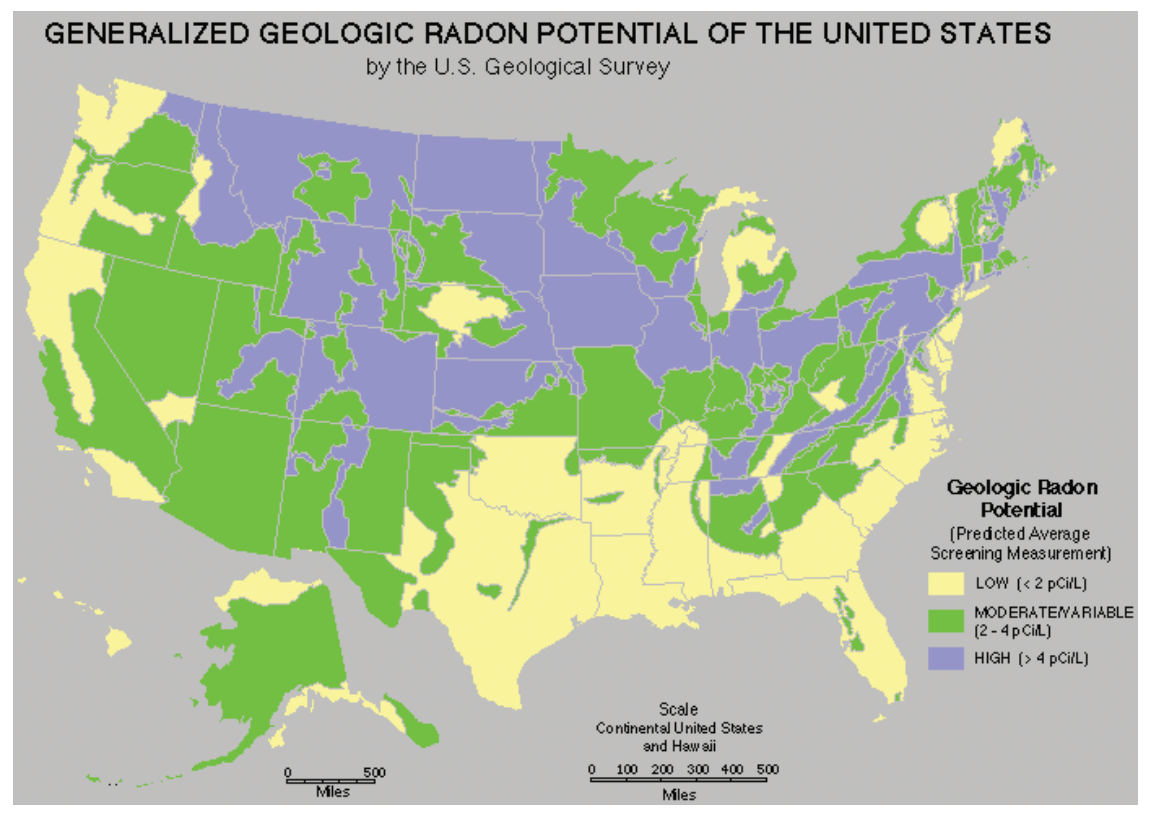

Map of the United States identifying risk for radon.

\section{Allergens and Asthma}

The predominant health outcome studied in conjunction with allergens in the home is asthma. Nearly 15 million asthma-related physician and outpatient hospital visits and almost 2 million asthma-related emergency department visits occurred in 2004. Environmental factors in homes that can contribute to the occurrence or severity of asthma include exposure to pests and pet dander (Akinbami and Schoendorf 2002), airborne and settled dust, dust mites (Institute of Medicine 2004), mold, and other conditions such as excess moisture. Studies show that $84 \%$ of U.S. homes have a bedroom 
with detectable levels of dust mite allergens; many of these have levels that can contribute to allergies or asthma (Arbes et al. 2003). Similarly, $82 \%$ of dwellings in the United States have detectable levels of mouse allergens (Cohn et al. 2004), and 63\% have detectable levels of cockroach allergens (Cohn et al. 2006). Low-income households and older homes are also among the factors frequently associated with U.S. residences having high concentrations of mouse and cockroach allergens (Cohn et al. 2004, 2006).

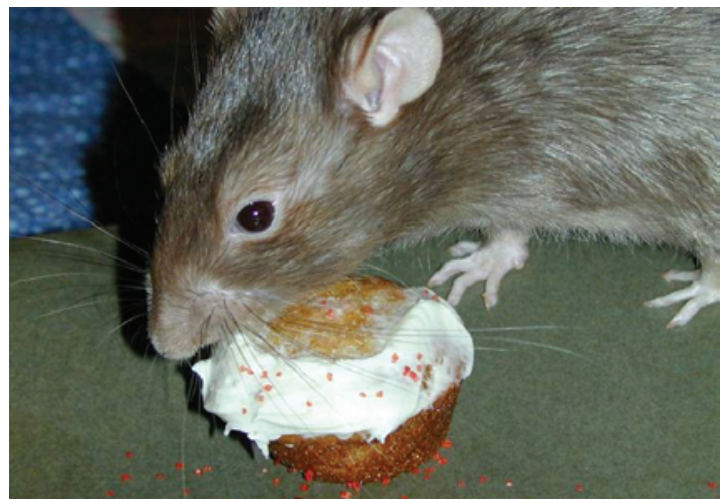

Mouse eating a cupcake.

Dampness and the presence of mold are also associated with asthma and other respiratory health complaints. Exposure to dampness and mold in homes is estimated to contribute to approximately $21 \%$ of current asthma cases in the United States, at an annual cost of $\$ 3.5$ billion (Mudarri and Fisk 2007). Moisture in homes supports the growth of mites and mold and the infestation of roaches, rats, and mice-all of which produce allergens that aggravate asthma and other preexisting chronic respiratory conditions, although it is not clear at what levels these contaminants cause allergic sensitization (Bornehag et al. 2004; Institute of Medicine 2004; Krieger and Higgins 2002; Mudarri and Fisk 2007).

\section{How Water Quality Affects Health}

In the United States, an estimated 4 million to 33 million cases of gastrointestinal illness associated with public drinking water systems occur annually (Colford et al. 2006; Messner et al. 2006). The presence of contaminants in water can lead to other adverse health effects; for example, pesticides can cause reproductive problems (Casarett and Doull 1991), polychlorinated biphenyls and lead can cause neurological disorders (Chevrier et al. 2007), and nitrates can cause methemoglobinemia or "blue baby syndrome" (Greer et al. 2005). Water contamination has many 
sources, including naturally occurring chemicals and minerals (e.g., arsenic, radon, uranium), local land-use practices (e.g., fertilizers, nitrates, pesticides, concentrated animal feeding operations), manufacturing processes, sewer overflow, and malfunctioning wastewater treatment systems (e.g., septic systems).

A particular area of concern with respect to water quality is the approximately 40-45 million persons in the United States who rely on private household wells for drinking water. Such systems are more commonly found in rural and suburban communities. Drinking water from public water systems is regulated by EPA, but private wells and small public water systems are unregulated, and testing for contaminants typically is left to homeowners. These wells can be contaminated with biological agents such as Cryptosporidium, E. coli O157:H7, and norovirus, all of which cause gastrointestinal illness. These wells can also be contaminated by chemicals, including pesticides and arsenic (U.S. Environmental Protection Agency undated c). Contamination of a private well is not only the concern of the household served by the well; it is also of concern to households using other nearby water supplies, including those that draw water from an aquifer. The safety of private wells can be improved by attention to issues including proper design, structure, installation, testing, and maintenance (Anderson et al. 2003; Centers for Disease Control and Prevention 1995).

\section{How Residential Chemicals Affect Health}

Chemicals in and around the home can contribute to poisonings and other health effects. Every 13 seconds, a poison control center in the United States fields a call about a potential poison exposure; more than $90 \%$ of these exposures occur in the home (Watson et al. 2004). Non-pharmaceutical products account for most poison exposures among children (McDonald et al. 2006). Most common among adult exposures are pain relievers, prescription medications, sedatives, cleaning products, and antidepressants (McDonald and Gielen 2006).

The long-term health effects of pesticide exposure are unknown ( $\mathrm{Lu}$ et al. 2001), but some studies suggest links between chronic exposure to pesticides and attention and behavioral problems and other neuropsychologic deficits as well as increased risk for asthma among children exposed during the first year of life (Chanda and Pope 1996; Rice and Barone 2000; Salam et al. 2004). In an estimated $74 \%$ of U.S. households, pesticides are used to prevent or exterminate insects and rodents (U.S. Environmental Protection Agency 2004). No national estimates of home pesticide exposure prevalence 
are available (U.S. Environmental Protection Agency 2007). However, in Washington State, $48 \%$ of reported pesticide-related health complaints were the result of pesticide use in and around the home or on food (Washington State Department of Health 1998).

In general, household cleaning products are safe when used as directed. Still, even when used as intended, detergents, bleaches, and a variety of other household cleaning products represent chemical exposure and may contribute to poor indoor air quality. For many household chemicals, a "safe" frequency and quantity of use in homes has not been established.

Infants and young children are most susceptible to the adverse health effects from use of household chemicals because they may be more likely to be exposed-they spend more time indoors, they have more hand to mouth behaviors - and their smaller and still developing bodies may be more susceptible (U.S. Environmental Protection Agency 1998). Under the age of thirteen, more males are victims of poison exposures, but among teenagers and adults, more females are involved (McDonald and Gielen 2006).

\section{How Housing Structure and Design Affect Health}

A home provides shelter, privacy, and safety and protects our physical and mental health. A residence that fails to offer these essentials through adequately designed and properly maintained interiors and exteriors is not healthy housing. How homes are designed, constructed, and maintained; their physical characteristics; and the presence or absence of safety devices have many effects on injury, illness, and mental health. Home conditions also influence the ability of people to participate fully in their community.

\section{Injuries}

In residential settings approximately 18,000 injury deaths occurred each year from 1992-1999 (Runyan et al. 2005a). Unpublished National Vital Statistics System data show that nearly twice as many residential unintentional injury deaths were reported in 2005. It is estimated that 12 million nonfatal residential injuries occur each year (Runyan et al. 2005b). Among children and adolescents younger than 20 years of age, an estimated $55 \%$ of unintentional deaths from injuries occur at home (Nagaraja et al. 2005). Children younger than 15 years and adults over age 70 years are at high risk for injuries in the home. Among children ages $0-14$ years, the leading causes of home injury deaths are fire/burns, choking/suffocation, drowning/submersion, firearms, and poisonings. 


\section{$\underline{\text { Falls }}$}

Falls alone account for $53.7 \%$ of all unintentional home injury deaths (Runyan et al. 2005a), 36\%-45\% of all nonfatal home injuries (Runyan et al. 2005b), and almost 4 million emergency department visits annually (Runyan et al. 2005b). More than one-third of all adults 65 years of age and older fall each year-with women $67 \%$ more likely to have a nonfatal fall than men (Centers for Disease Control and Prevention 2006; Rubenstein et al. 2007). As a result of falls, many elders experience devastating consequences such as broken bones and head injuries (Rubenstein et al. 2007). An estimated 1.5 million fall injuries among children under age 15 years occur in the home and require medical attention each year (Runyan et al. 2005b). Fall rates among children under age 5 years are second only to those observed in the elderly population (Casteel and Runyan 2004). Important fall-related hazards for children in the home include baby walkers, stairways, windows above ground level, and furniture (McDonald and Gielen 2006). Beds have been identified as the leading product in the percentage of nonfatal home injury costs for children under age 5 years, followed by stairs, floors, and tables (Zaloshnja et al. 2005). Outside play equipment, including play sets and trampolines, can also be dangerous for children. Most injuries occur when a child falls from the equipment onto the ground (MacKay 2003).

\section{Fire and Burns}

Housing design and construction materials can directly influence occupants' level of injury risk from fires (Krieger and Higgins 2002). In 2006, house fires were responsible for approximately 2,580 deaths (Karter 2007) and injuries to another 12,925 persons (not including firefighters) (Karter 2007). Most fire victims do not die from burns, but from smoke or toxic gases (Hall 2001). A primary risk factor for death and injury in residential fires is absent or nonworking smoke alarms (Ahrens 2004; Istre et al. 2001). Studies show that even though $90 \%$ of homes have smoke alarms, only about three-quarters of the alarms are functioning (Ahrens 2007; Smith 1993). When a fire occurs in a home with a functioning smoke alarm, the risk for death is decreased by 40\%-50\% (Ahrens 2004). Children, persons with disabilities, and those who live in poverty and in rural areas are the groups most likely to live in homes without working smoke alarms (Ballesteros and Kresnow 2007) and, as a result, to die in house fires or suffer serious fire-related injuries (Istre et al. 2001; Warda et al. 1999). Older residents are at especially high risk for dying in a smoking-related house fire (U.S. Fire Administration 2006). Additional groups at high risk 
for dying in a house fire include African Americans and people who live in substandard homes where emergency egress is often compromised (Hannon and Shai 2003).

Scalds and thermal and electrical burns also contribute to home injuries. In 2007 an estimated 38,647 children less than 5 years old were seen in U.S. emergency departments for a burn that occurred at home (U.S. Consumer Product Safety Commission undated a). Exposure for 2 seconds to water at a temperature of $150^{\circ} \mathrm{F}$ can result in a full thickness burn (Moritz and Henriques 1947). Environmental modifications can, however, ameliorate many of these scald burn injuries.

\section{Drowning}

Swimming pools account for $60 \%-90 \%$ of drownings among children 0-4 years old, and each year about 300 children under 5 years old drown in swimming pools, usually a pool owned by their family (U.S. Consumer Product Safety Commission undated b). More than half of drownings among those ages 5-24 years are in the victim's home pool, and 22\% are at the homes of friends, neighbors, and relatives (Saluja et al. 2006). Among infants, the majority (78\%) of drownings occur in the home, with $71 \%$ of these in bathtubs and $16 \%$ in buckets (Brenner et al. 2001).

\section{Suffocation and Strangulation}

Children sustain approximately 18,000 suffocation injuries each year (Centers for Disease Control and Prevention 2007b). More than half (60\%) of infant suffocation occurs in the sleeping environment ( $\mathrm{McD}$ onald et al. 2006). Cribs and playpens are responsible for half of all nursery product-related deaths among children ages 5 and under (McDonald 2002). Strangulation deaths from window cords happen most often when children are in places their parents think are safe, such as in a crib or in a child's bedroom. From 1991 to 2000, the U.S. Consumer Product Safety Commission received reports of 160 strangulations involving cords on window blinds (U.S. Consumer Product Safety Commission undated c). Fatal window-cord strangulations have a mortality rate of 0.14 per 100,000 persons per year in the United States (Rauchschwalbe and Mann 1997).

\section{Firearms-related Injuries and Deaths}

Between 1990 and 2000, an estimated 11,509 unintentional firearm deaths occurred (Miller et al. 2005). Nearly 600 unintentional firearm-related deaths occur annually in homes (Runyan 2005a). Studies indicate that for 
each $1 \%$ increase in the number of homes in a community where firearms are safely stored, the unintentional firearm death rate decreased by $4 \%$.

\section{Elevated Lead Levels}

Between 1999 and 2004, an estimated 240,000 children 1-5 years of age had blood lead levels $\geq 10$ micrograms per deciliter $(\mu \mathrm{g} / \mathrm{dL})$, and most of these elevated levels were a result of lead paint hazards in and around their homes (Jones et al. 2009). Lead exposure can result in lasting impairment of a child's development and behavior such as decreased IQ and attention span and increased risk for delinquent behavior (Centers for Disease Control and Prevention 2005d). Although in the United States lead has been banned from paint intended for residential purposes since 1978, older houses with lead paint remain. These homes can expose children to lead when maintenance is deferred and the paint deteriorates, or when the property is renovated or painted without using lead-safe work practices to control dust and soil contamination. In the United States in 2000, an estimated 1.2 million housing units with lead-based paint hazards were home to children younger than 6 years of age (Jacobs et al. 2002). Other sources of lead exposure in the home include lead water pipes and solder used in plumbing, as well as toys and ceramics (Levin et al. 2008). Children of minority race/ethnicity and children whose families are poor are much more likely to be exposed to lead in their homes.

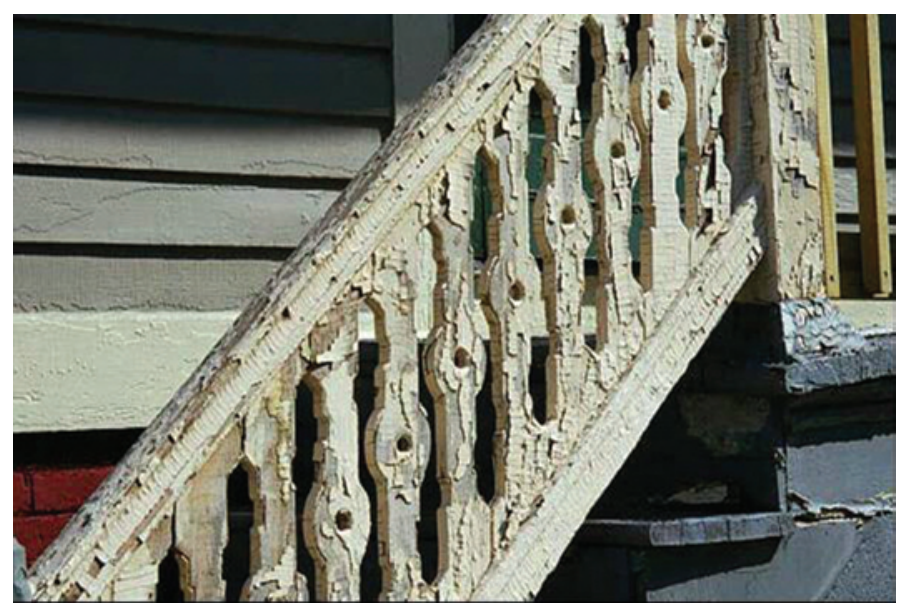

Outdoor stairs to a house featuring a banister with badly peeling paint. 


\section{Mental Health}

Poor housing conditions, including crowding and inadequate lighting, are associated with risk for poor mental health. Poor-quality, overcrowded, multifamily homes are associated with outcomes that include aggression and withdrawal, lower general health status (Dunn et al. 2004; Evans et al. 1996; Lepore et al. 1992; Regeoczi 2003), and psychological distress, particularly among women and children (Evans et al. 2001). Lack of light (e.g., from inadequate number and placement of windows) is related to depression (Golden et al. 2005; Kripke 1998). Although some studies have suggested an association of dampness or mold with depression (Shenassa et al. 2007), the Institute of Medicine concluded that evidence is insufficient to determine whether an association exists between either damp indoor environment or presence of mold and neuropsychiatric symptoms (Institute of Medicine 2004).

\section{Structural Deficiencies}

In 2005, about 2 million people in the United States lived in severely inadequate homes (U.S. Department of Housing and Urban Development 2007). The U.S. Census Bureau defines severely inadequate housing as homes without heat, hot water, or electricity, or housing with significant upkeep problems and structural defects (U.S. Census Bureau 2006). Although wear typically increases as homes age, these problems are not limited to older homes. Some modern building practices, inferior building construction, and poor building design also can exacerbate conditions that threaten health. For example, water incursions in structures that lack adequate ventilation and drainage increase the risk for mold growth, which is associated with increased risk for asthma and perhaps other health problems (Institute of Medicine 2000, 2004; U.S. Department of Health and Human Services 2005a). Poor design and maintenance of both old and new homes can result in injuries, poisoning, and poor mental and physical health.

\section{Accessibility}

For the elderly and for persons with disabilities, home design and construction can hamper-sometimes substantially-ease of mobility and interfere with access to important features of the house like toilets, sinks and bathtubs, and shelving in cupboards and closets. Approximately 5.5 million disabled persons in the United States face barriers to community participation because of building design or because of the absence of sidewalks (Hendershot 2004). Additionally, inappropriate design and construction can increase the 
possibility of injury from falls among older adults and can deny some the opportunity to remain at home and more comfortably "age in place" rather than move to an assisted-living facility or nursing home.

\section{How Behaviors Contribute to Adverse Health Related to Homes}

Individual resident behavior is an important aspect of healthy and safe home environments. Yet a large gap exists between what we know about how to make homes healthier, and what we actually do. For example, research indicates that although parents say they support injury-prevention behaviors, their home lives do not reflect adequate injury-prevention practices (Gielen et al. 1995). In a survey of parents, 59\% reported they did not use stair gates; only $37 \%$ had their water heater temperature set at $125^{\circ} \mathrm{F}$ or less, and $27 \%$ did not have smoke alarms (Gielen et al. 1995).

\section{Disparities in Access to Safe and Healthy Homes}

Many of the disparities in health status among subpopulations may be linked to poor access to safe and healthy homes, which is most prevalent among lower income populations, populations with disabilities, and minority populations. In $2005,6 \%$ of all U.S. residents and $14 \%$ of low-income renters lived in homes with severe or moderate physical problems, such as water leaks that can cause mold growth and trigger allergic reactions and asthma attacks (U.S. Census Bureau 2006). Low-income minority renters in nonmetropolitan areas have a higher incidence of housing quality problems compared to other renters or homeowners (Joint Center for Housing Studies of Harvard University 2008). Minority parents also are substantially less likely than are white parents to have safety measures in their homes such as stair gates, safety latches on cabinets, or lower hot-water thermostat settings (Flores et al. 2005).

Housing-related illness and injury are not, however, the exclusive domain of lower-income groups. Higher income populations also experience housingrelated health problems. In some communities, more than $40 \%$ of the middleclass suburban population lives in homes with elevated levels of cockroach allergens (Matsui et al. 2003). High-density housing may be associated with negative psychological consequences for the affluent, as well as for poorer populations (Evans et al. 2000). 


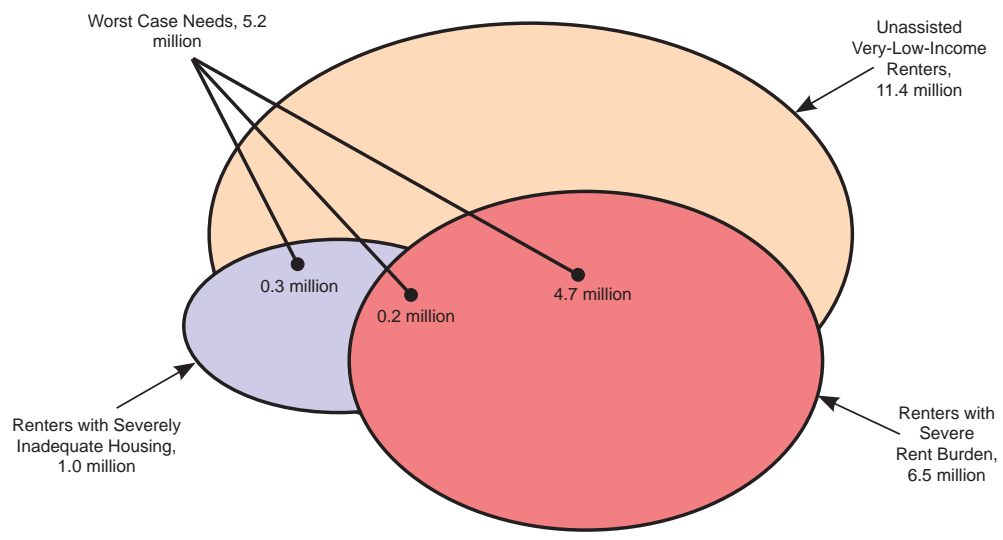

Source: HUD-PD\&R tabulations of the 2003 American Housing Survey

Venn diagram describing rent burden and inadequate homes showing the intersection between unassisted very-low-income renters and (a) renters with severely inadequate housing, (b) renters with severe rent burden, and (c) the worst case needs, the majority of whom are unassisted very-low-income renters.

\section{Relationships among Community Characteristics, Health, and Homes}

Broader community characteristics have important effects on homes and their residents. Homes also have effects on the broader environment.

\section{Weather and Natural Disasters}

Regionally specific health concerns tied to housing include extreme weather (e.g., heat waves and winter storms) and natural disasters, including tornados, hurricanes, earthquakes, volcanic eruptions, floods, and wildfires. Forest fires and volcanoes harm air quality. Hurricanes and floods can contaminate water supplies and damage wastewater facilities. Any of these disasters can spread contaminated materials into the home environment. Additionally, some areas of the United States are prone to floods, tornadoes, or wildfires - such extreme weather events commonly cause serious injuries and fatalities. Residents unable to keep warm during cold weather or to keep cool during very hot weather are exposed to conditions that can lead to serious illness and even death. Since 1995, hundreds of deaths during heat waves have been documented, with mortality most prevalent among the elderly, the socially isolated, and those living in homes without air 
conditioning (Naughton et al. 2002). Improper siting and design of homes can contribute to the adverse health consequences related to extreme weather and natural disasters.

\section{Noise}

At very high levels, the most obvious effect of exposure to excessive noise is hearing loss. There is concern that hearing loss may not just be the result of occupational exposure but may result from exposure to noise in the living environment (Passchier-Vermeer and Passchier 2000). Noise levels that commonly occur in homes may also result in sleep disturbances, cardiovascular and psychophysiological problems, performance reduction, increased annoyance responses, and adverse social behavior (Centers for Disease Control and Prevention and U.S. Department of Housing and Urban Development 2006). Exposure to noise disproportionately affects low-income children and is likely caused by poor urban planning that places homes adjacent to airports, railroad yards, highways, and other sources of noise. Living in crowded neighborhoods and in substandard or poorly designed homes have also been implicated as contributing to noise in homes (Evans and Marcynyszyn 2004).

\section{Green Homes}

Green homes are designed to use less energy and fewer natural resources than standard homes and to create less waste; they also may be healthier for residents. A green home incorporates smart design, technology, construction, and maintenance elements to improve the health of those who live inside and to reduce negative impacts on the environment.

Compared with a standard home, a green home should protect the environment through reduced use of energy, water, natural resources, and reduced production of waste. For example, buildings represent $39 \%$ of primary energy use in the United States and consume $70 \%$ of electricity generated (National Center for Healthy Housing 2008; U.S. Department of Energy 2006). Efficient plumbing and bathing fixtures, drought-tolerant landscaping, and water-conserving irrigation systems help green homes use, on average, $50 \%$ less water than used by standard homes. Construction of a green home generates $50 \%$ to $90 \%$ less construction waste that usually ends up in landfills. Green homes may also be healthier for residents if, for example, they produce less indoor air pollutants, however the extent to which green technologies promote health of residents is still an area that requires much more research. 


\section{Housing Instability and Homelessness}

People with low-household incomes, the elderly, people with disabilities, and minority populations are least likely to have access to safe, healthy, affordable, and accessible homes. Each year in the United States, an estimated 2.1 million adults and 1.3 million children are homeless (Burt et al. 2001). For those who are homeless, the lack of a place to live is a daily, distressing fact of life. For approximately 2 million families at the bottom of the socioeconomic ladder, housing is so severely deficient that it is barely adequate (Joint Center for Housing Studies of Harvard University 2004). For nearly 18 million Americans, more than $50 \%$ of family income is consumed by housing costs. Consequently, these families cannot meet expenses for other basic needs such as medical care, childcare, heating and gasoline, and food (Joint Center for Housing Studies of Harvard University 2008), and with fuel costs rising, their ability to meet these expenses may be further compromised.

People with low incomes may not be able to secure adequate, affordable homes and may be forced to move often. This housing instability also contributes to adverse health outcomes, including increased asthma morbidity, tuberculosis, and developmental delay, as well as school failure and delinquency (Buckner 2008). Those who are both homeless and chronically ill are confronted by a unique set of problems as they try to maintain medical regimes related to asthma, diabetes, or AIDS (Leaver et al. 2007; Matte and Jacobs 2000). Without an adequate supply of affordable homes, healthy homes cannot be achieved. 


\section{Section 3 \\ Promoting Healthy Homes through Prevention}

Illnesses and injuries related to homes are not inevitable. Many housing hazards and the injuries and illnesses resulting from them can be reduced or eliminated by proper design of new construction, modification of existing home structures, and changes in housing-related behaviors. Successful prevention of housing-related disease and injuries through healthy homes depends on how architects, building inspectors, property owners, maintenance and remodeling workers, and residents incorporate healthy housing knowledge into their practices and into their day-to-day activities. Many simple changes can promote health and safety at home. In addition, housing interventions can also improve the availability, accessibility, and environmental friendliness of homes. This section presents well-documented, evidence-based interventions.

\section{Improving Air Quality}

Two effective ways to reduce indoor air pollution levels are to eliminate or reduce emissions from indoor sources and to improve ventilation. Usually the most effective method is to control emissions, for example by eliminating smoking, adjusting gas stoves to minimize emissions, using paints and coatings that emit low levels of volatile organic compounds, using low-emitting building materials such as wood products that emit low levels of formaldehyde, and using cleaning products that emit low levels of air pollutants. In typical houses, the 2007 American Society of Heating, Refrigerating and Air Conditioning Engineers standard (ASHRAE 62.2) requires a mechanical ventilation rate of about 50 cubic feet per minute or 25 liters per second; larger houses have a higher rate. In some cases, proper ventilation can also be achieved by opening windows and doors for a period of time each day and by using exhaust fans in kitchens and bathrooms (Centers for Disease Control and Prevention and U.S. Department of Housing and Urban Development 2008).

\section{Smoke-free Homes}

The best way to maintain a smoke-free house is to refrain from smoking. In addition, adopting smoke-free rules in homes reduces involuntary exposure to secondhand smoke and improves health. Opening a window; 
sitting in a separate area; or using ventilation, air conditioning, or a fan cannot eliminate secondhand smoke exposure. The only way to fully protect yourself and your loved ones from the dangers of secondhand smoke is through 100\% smoke-free environments (U.S. Department of Health and Human Services 2006).

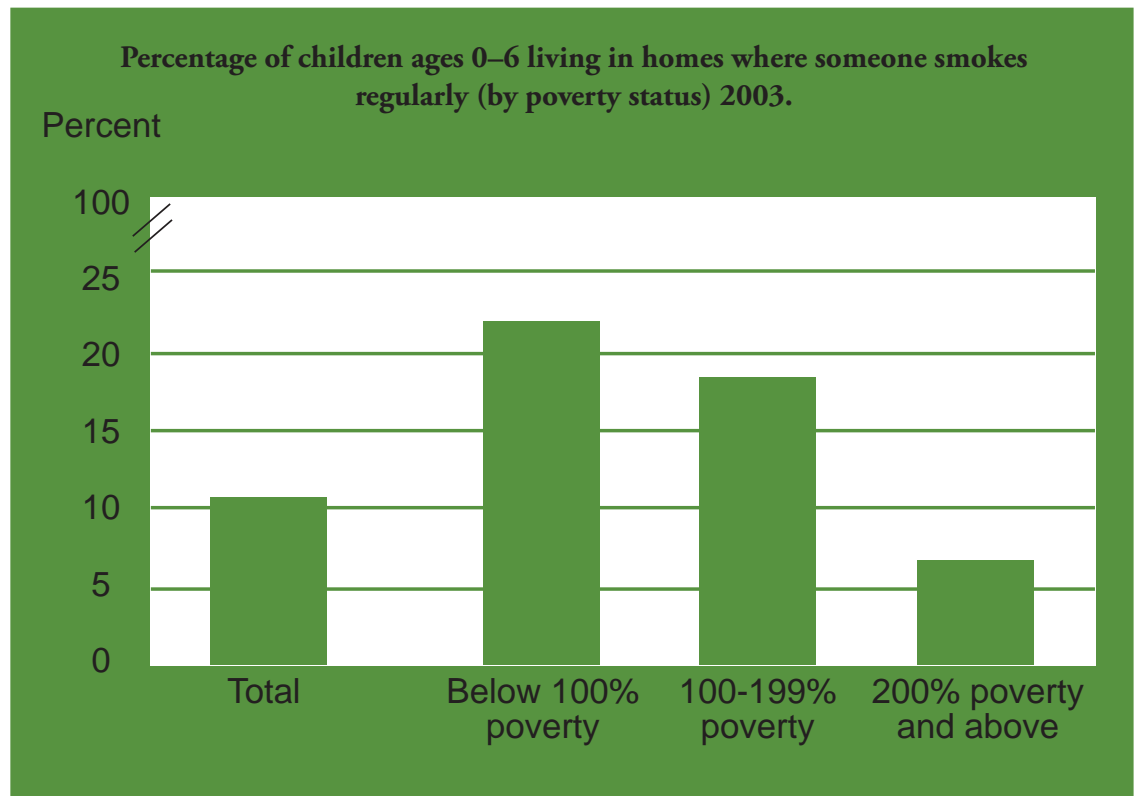

SOURCE: U.S. Environmental Protection Agency, Indoor Environments Division, National Survey on Environmental Management of Asthma and Children's Exposure to Environmental Tobacco Smoke

\section{Carbon Monoxide Poisoning Prevention}

Removing or controlling carbon monoxide sources in the home is the most important way to prevent carbon monoxide exposure. For example, gas generators, gas grills, and other fuel-burning appliances should never be operated in the house. Converting from wood stoves or kerosene heaters may decrease both carbon monoxide and particulates in the home, although this may not always be practical. In addition, installing and maintaining carbon monoxide detectors can prevent death and injury from carbon monoxide exposure (Centers for Disease Control and Prevention 2005c).

\section{$\underline{\text { Radon Gas Mitigation }}$}

An active radon test determines whether radon gas results exceed the EPA action level of $4 \mathrm{pCi} / \mathrm{L}$. EPA estimates that $6 \%$ of U.S. homes have average concentrations at or above the $4 \mathrm{pCi} / \mathrm{L}$ action level (U.S. Environmental 
Protection Agency undated a). Radon mitigation using a soil depressurization system can effectively prevent radon from entering the house and reduce the risk for lung cancer (U.S. Department of Health and Human Services 2005b). Incorporating radon-reducing features while building a home is less expensive than installing a radon-reduction system in an existing home.

\section{$\underline{\text { Reducing Allergens and Asthma }}$}

Homes should be designed, operated, and maintained to prevent water intrusion and excessive moisture accumulation. Moisture can be controlled by repairing water leaks, installing suitable insulation to avoid condensation, and ventilating rooms properly. When water intrusion and moisture accumulation are discovered, the sources should be identified and eliminated quickly to reduce mold growth and to reduce infestations of cockroaches and rodents (Institute of Medicine 2004). Allergen levels can be controlled by vacuuming and cleaning hard surfaces. Mold growth should be eliminated in a way that limits the possibility of recurrence and that limits exposure of the occupants and persons conducting the remediation. Mold should not be cleaned using mixtures of ammonia and bleach, which may produce poisonous gas. Porous materials such as ceiling tiles, wall boards, and fabrics that cannot be cleaned should be removed and discarded (New York City Department of Health 2000; U.S. Environmental Protection Agency 2001). Because dead mold may still retain its allergic or toxic properties, replacing rather than cleaning is often the best mitigation option (Foarde 1998; Institute of Medicine 2000). In addition, frequent washing of plush toys and bedding, using mattress and pillow covers, and keeping pets out of bedrooms has been demonstrated to reduce exposure to allergens (Krieger et al. 2005).

\section{Improving Water Quality}

There are several important things to know about homes that are connected to small community water systems or that have a private well: build wells away from septic systems and other wastewater systems, do not use wastewater systems to dispose of toxic chemicals, and know when and how to test wells (Centers for Disease Control and Prevention undated). Steps for proper maintenance and protection of private wells include periodic inspection of exposed parts of the wells to identify missing or worn parts or cracks, annual disinfection using bleach or hypochlorite granules, and annual testing for bacteria and chemical contamination (Centers for Disease Control and Prevention and U.S. Department of Housing and Urban Development 2006). 


\section{Reducing Harmful Chemicals}

\section{Pesticide Exposure Prevention}

A safer alternative to exclusive reliance on chemical pesticides is integrated pest management (IPM). IPM uses the least toxic practical baits and insecticides, thus reducing both insect pests and reliance on chemical pesticides (Klitzman et al. 2005; Williams et al. 2006). Most household pests can be controlled by eliminating the pest's habitat inside and outside the house, keeping pests out using building or screening techniques that prevent entry, eliminating food from areas where pests can make their homes, and, when necessary, using pesticides appropriately (Centers for Disease Control and Prevention and U.S. Department of Housing and Urban Development 2006).

\section{Household Chemicals and Medicines}

A number of simple actions can help to assure that household chemicals including household cleaning products, pesticides, medicines, gasoline, car polishes, and pool-cleaning chemicals can be used safely. Eliminate dangerous chemicals that do not need to be in the house. Do not repackage chemicals. Be sure all chemicals are labeled, read the labels on all products, follow directions regarding use and disposal, and dispose of chemicals safely (U.S. Environmental Protection Agency undated d). Store household chemicals and medicines with "keep out of reach of children" labels in locked cabinets. Use childproof caps on prescription medications to protect children. Lock outbuildings that store chemicals such as automotive supplies, pool cleaners, and agricultural pesticides and fertilizers.

\section{Improving Housing Structure and Design}

How homes are designed, constructed, and maintained; their physical characteristics; and the presence or absence of safety devices can promote the health of residents. Housing structure has an impact on mental health and the occurrence of injuries and diseases, as well as promoting accessibility for elders and people with disabilities.

\section{Preventing Injuries}

\section{Fall Prevention}

By installing grab bars in bathtubs and showers and adding handrails and good lighting in stairwells, homes can be designed and constructed to protect elderly occupants from fall-related injuries. Many homes currently do not have 
these simple safety features. For example, $35 \%$ of homes with stairs do not have handrails (Marshall et al. 2005). Interventions that can help to prevent childhood fall injuries include window guards (Barlow et al. 1983); stair gates, balcony railings less than 4 inches apart, and window locks or guards for windows above ground level (McDonald et al. 2006).

\section{Fire and Burn Prevention}

The leading cause of residential fire deaths is smoking. Smokers should be advised to quit. When a fire occurs in a home with a functioning smoke alarm, the risk for death is decreased by $40 \%-50 \%$ (Ahrens 2004). To reduce the risk of deaths from fires, smoke alarm batteries should be checked regularly-for example, when clocks are reset to daylight or standard times. New home construction should include hard-wired smoke alarms that do not depend solely on battery power. Residential sprinklers may be a promising strategy to prevent deaths and injuries due to fires (Warda and Ballesteros 2007). Preparing and practicing a fire escape plan, especially teaching fire escape skills to children, can minimize injuries and death from fires (McDonald et al. 2006; Thompson et al. 2004).

Successful strategies to decrease burns include reducing the temperature in water heaters to $120^{\circ} \mathrm{F}$; installing hot water temperature limiters at the faucet; using roll-up cords for electric coffee pots; installing covers on electrical outlets; and using pots, pans, and kettles designed to be less likely to tip and spill hot liquids (Staunton et al. 2007).

\section{Drowning Prevention}

Drowning at home can be prevented by having proper fencing around swimming pools. When combined with self-closing and self-latching gates, four-sided fencing provides a passive intervention that prevents unintended access to pools by small children (Quan et al. 2007). To help prevent drowning, parents should be within arms length of children who are bathing or playing around water (Committee on Injury, Violence, and Poison Prevention 2003).

\section{$\underline{\text { Suffocation and Strangulation }}$}

Parents and caregivers should be aware of the types of objects that pose a strangulation or suffocation risk for children and become familiar with methods to reduce this risk. Infants should be placed on a firm sleep surface, such as a safety-approved crib mattress, and soft objects or loose bedding should not be placed in a crib. Loop window blind and drapery cords should 
be tied up out of reach or the ends should be cut and retrofitted with safety tassels. The inner cords of blinds should be fitted with cord stops.

\section{Firearm Injury Protection}

To prevent firearm injuries and deaths, firearms should be stored locked and out of reach of children and should be equipped with trigger locks. These simple measures are often not taken. For example, in an estimated $13 \%$ of U.S. homes with firearms, those firearms are loaded and unlocked (Miller et al. 2005).

\section{Preventing Elevated Lead Levels}

Lead hazard control or elimination in residences has been evaluated and can reduce the likelihood that additional children will suffer elevated blood lead levels (Brown et al. 2001; U.S. Department of Housing and Urban Development 1995). Policies can also limit lead exposure from other sources, such as consumer products.

\section{Improving Mental Health}

Home design elements can foster improved mental health. For example, building designs with window placement that allows adequate light and views of natural landscapes may improve psychological well being (Ulrich 1984; Wells 2000). Home design elements that increase the probability of social interaction among neighbors - for example, front porches_can enhance social cohesion and support (Buka et al. 2003). Crowding in housing units can be prevented by providing an adequate supply of affordable homes. Certain design features such as greater ceiling height (Savinar 1975), windows (Desor 1972), brighter lighting, and visual distractions such as pictures on walls (Bell et al. 2001) can help reduce the perception of crowding (Baum and Valins 1979). Other factors, such as social support, can help reduce the negative impact of crowding (Lepore et al. 1992). Efforts to build social support may be a useful adjunct to design solutions.

\section{Remedying Structural Deficiencies}

When enforced, housing and building codes have resulted in better constructed and maintained buildings and in improved health. For example, strict housing code enforcement has been demonstrated to reduce the likelihood of death in residential fires (Cummins and Jackson 2001) and lead poisoning in homes where lead-poisoned children live (Brown et al. 
2001). A large number of programs, codes, and regulations exist that have the potential to influence changes in the environmental conditions in homes. The development of clear design standards increases the potential to address a wider range of health hazards through building and housing codes. Incorporating public health considerations into the planning process will maximize the opportunities for healthy building and development.

\section{Improving Accessibility}

Designing and remodeling using wide doorways and building entrances without steps can help older persons and those with disabilities remain connected with their communities. Creating an adequate supply of homes accessible for elders and for people with disabilities will result in significant public health improvements. Following universal design guidelines or meeting minimum accessibility requirements, including easier visits to families and friends for elders and people with disabilities_-also known as visitability — could improve safe accessibility to homes and to communities.

\section{Encouraging Safe and Healthy Behaviors}

Individual resident behavior and prevention patterns with regard to home hazards contribute to health and safety at home. Behaviors that affect health result from the interplay of many economic, social, and cultural factors. Still, changing behaviors is not easy, even when people are aware of the effects of certain behaviors on personal health or the health of their families. Behavior change needs to be understood in the context of large systems-social systems, cultural systems, education systems, and the public health system.

\section{Reducing Disparities in Access to Healthy and Safe Homes}

Focusing on properties that pose the greatest health risks; that is, those properties that are older, low-income, or in substandard condition, will yield the greatest improvement in health outcomes. This will also help address the striking health disparities borne by low-income and minority families. Indeed, for all important exposures and health problems, it is essential to emphasize making improvements among the most affected populations as well as in the population as a whole. Existing funds and policies for "home improvement" programs may, for example, provide effective strategies for improving individual- and community-level health disparities. 


\section{Addressing Community Factors that Affect Health and Homes}

\section{Weather and Natural Disasters}

Siting and design of homes can protect against adverse health effects related to weather and disasters. Although no building can be completely disaster-proof, good design and materials will minimize structural damage and will safeguard the lives of occupants during a major disaster or extreme weather event. Disaster resistance is best achieved by following modern building codes and standards. Urban planning and zoning can ensure that homes are not built in locations at high risk for specific types of disasters.

People can minimize their risk for disaster-related adverse health effects by learning about the types of disasters that are most likely to occur where they live. People can learn about the local warning signals and systems. Developing home response plans can also minimize health risks by, for example, maintaining a disaster survival kit with an adequate supply of water and necessary prescription medications. Communities can help minimize consequences of disasters by adequate response planning.

Finally, the responses of people to natural events should avoid harm to themselves or the environment. For example, portable generators or supplemental heating devices should be used appropriately so that they do not release deadly carbon monoxide. Proper installation and maintenance of heating and cooling systems can prevent hypothermia and hyperthermia (Centers for Disease Control and Prevention and U.S. Department of Housing and Urban Development 2006) when temperatures are extremely cold or hot.

\section{Noise}

Noise abatement housing design strategies have been proposed but have been inadequately tested. However, reducing the sources of noise in and around the home and designing buildings to control the transmission of sound may reduce noise and its adverse health consequences. (Berglund et al. 1999).

\section{Green Homes}

A home can be built green or can be renovated to add green features. Individual homebuyers and builders can incorporate green features when siting the home, designing, building or renovating, and selecting materials.

Siting homes to maximize the benefits of sunlight can help reduce energy consumption and increase entry of natural light. Selection of construction 
materials and interior finish products with zero or low emissions can improve indoor air quality. Examples of nontoxic materials may include wheat-derived strawboard; natural linoleum made from jute and linseed oil; paints with few or no volatile organic compounds; and toxin-free insulation made from soybeans, recycled paper, or even old denim. Incorporating effective and efficient natural or mechanical ventilation systems may also reduce indoor air pollutants.

Cleaning practices, water use, and appliances also contribute to a green home. When building, renovating, and maintaining the home, people can use lesstoxic materials such as paints, coatings, wood products, and cleaning supplies. Selecting new ENERGY STAR ${ }^{\circ}$-qualified appliances results in energy efficiency. Water can be conserved by using products with EPA's WaterSense label. Many local and state governments, utility companies, and other entities across the country offer rebates, tax breaks, and other incentives for adding ecofriendly elements to homes.

\section{Housing Instability and Homelessness}

Preventing homelessness requires a communitywide approach to home instability and adaptation of successful models to local conditions. Communities where these and other approaches have been implemented have had substantial reductions in the number of homeless people (National Alliance to End Homelessness 2007). Targeting home subsidies to homeless families was found to have the greatest effect in reducing homelessness in several communities (Rog et al. 1995; Shinn et al. 1998; Stojanovic et al. 1999). Adults who are severely mentally ill require supportive services in conjunction with permanent homes. Mediation also has been shown to prevent homelessness-even in cases where a property owner has filed for eviction-by resolving the dispute and thus preventing eviction (Burt et al. 2007). Another commonly used approach to prevent homelessness is cash assistance for families with past-due rent.

Programs that improve home choices can also reduce home instability by providing families with the ability to access safe and healthy homes. In addition, some evidence indicates that moving from a neighborhood of concentrated poverty to a neighborhood with mixed income levels improves health and well-being. In one study, asthma and injury rates among children and behavioral problems among boys were significantly reduced in families that moved from public housing projects to more affluent neighborhoods (Katz et al. 2001). Other studies have found lower rates of obesity and improved mental health for adults and girls (Katz et al. 2001; Leventhal and Brooks-Gunn 2003; Orr et al. 2003). 


\section{Section 4 \\ Homes and Health Research}

\section{The Importance of Research}

Although in the last decade research has matured that demonstrates the link between specific home conditions and health, significant knowledge gaps remain. Addressing these gaps will require research linking home conditions with specific health outcomes. That effort must also account for personal, housing unit, neighborhood, and community-level factors as well as applied research that evaluates the effectiveness of home interventions in different communities. Unless the effectiveness of home improvements to protect health is carefully studied, the risk remains that families, property owners, and government agencies responsible for providing housing assistance will undertake expensive but ineffective interventions.

Because the poor are more likely to live in unhealthy homes, investigating the economic tension between making homes healthier and keeping it affordable is one critical area of study. If the simultaneous importance of individual- and social-level determinants of health is recognized, it follows that housing is a likely mediator between socioeconomic status and health. Recent evidence (Dunn et al. 2004; Jargowsky 1997; Shenassa et al. 2004) suggests that housing may in fact be a fulcrum between individual- and social-level determinants of health.

\section{Research Methods}

Improvements are needed in the scientific methods available for formative research in this area. Unique challenges remain, however, in conducting intervention and prevention research in homes, and these issues would need to be addressed (Bingenheimer and Raudenbush 2004; Institute of Medicine 2005).

Consensus is needed to standardize home hazard identification systems. One recent review showed wide variation in existing home inspection protocols (Jacobs 2006). A better formal determination of what constitutes a "healthy" house and standardized assessment methodology would contribute to a more consistent evaluation. In that regard, the Centers for Disease Control and Prevention (CDC) and the U.S. Department of Housing and Urban Development (HUD) recently released environmental healthy home inspection recommendations that begin to address that need (Centers for 
Disease Control and Prevention and U.S. Department of Housing and Urban Development 2008).

Intervention studies in this area raise multiple and difficult issues in study design and analysis. Randomized studies can be difficult or impossible to conduct, multiple influences at the individual and group levels affect outcomes, and multiple risk and protective factors simultaneously influence multiple outcomes. Statistical methods that can address these issues need to be designed and disseminated.

\section{Costs and Benefits}

Progress made in achieving safe and affordable homes will depend, perhaps in large part, on our ability to demonstrate that healthy homes are feasible, affordable, and beneficial (Proscio 2004). In some cases, studies that assess the costs and benefits of interventions to improve homes show a net economic benefit to society. For example, preventing lead exposure among children has been estimated to improve their intelligence and behavior, resulting in increased earning potential and lower health care costs, which in turn result in economic benefits ranging from $\$ 110$ to $\$ 319$ billion dollars annually (Brown 2002; Grosse et al. 2002). Other interventions have been demonstrated to improve health outcomes at an acceptable cost. For example, home-based environmental interventions for asthma can reduce the number of unscheduled medical visits, symptom days, and beta-agonist inhalers at the cost of less than $\$ 28$ per symptom-free day (Kattan et al. 2005). Similar economic benefits could result from injury prevention. National adoption of childproof cigarette lighters has reduced smoking-related injuries and also produced net cost savings to society. Many home interventions are needed that simultaneously result in multiple health benefits and in economic evaluations that consider benefits holistically. For many interventions, however, good quality economic information is not yet available to guide policy. For example, although the lifetime costs of serious falls experienced in 2000 is estimated at over $\$ 80$ billion, data on the benefits of housing interventions to reduce or eliminate falls are not available (Corso et al. 2006).

\section{Additional Topical Research}

For many areas discussed in this document, additional research is needed that will better quantify the relationship between homes and health. For other areas, more research is needed to identify the most effective, feasible, and cost-effective interventions. Finally, when effective interventions are known, additional research on how to translate them to widespread use may be 
needed. This section provides selected examples.

- Clarify the health impact of the home environment:

- Quantify the benefits of various green practices on health and the environment. This research should also assess whether there are tradeoffs between environmentally friendly practices and health.

- Define effects of noise in households on physical health, mental health, and well-being.

- Clarify relationships of home characteristics and mental health:

- Define effects of exposures to natural light, mold, crowding, and multifamily homes on mental health outcomes.

- Assess and reduce risk from household chemicals:

- Determine safe levels and frequency of use of household chemicals, such as pesticides, particularly to sensitive populations, such as children, pregnant women, and seniors.

- Better evaluate the effectiveness and cost effectiveness of home interventions on health outcomes including asthma, mental health, well-being, and consequences of noise.

- Assess the effectiveness of interventions to prevent or reduce the duration of homelessness:

- Perform additional research on ways to more rapidly translate effective interventions in homes into policy and practice. 


\section{Section 5 \\ Ensuring Healthy Homes: Taking Action for the Future}

This Call to Action builds on the Surgeon General's report on healthy indoor environment (U.S. Department of Health and Human Services 2005a), the research presented at the seventh National Environmental Public Health Conference sponsored by CDC in December of 2006, and the thoughtful contributions of subject-matter experts from a number of federal agencies (see Acknowledgements). These goals are not isolated; rather, they are highly integrated components of an overall approach to promote healthy homes in the United States. They call on people from many walks of life to join in a discussion about healthy homes issues; to make informed, shared, and compassionate decisions; and to develop imaginative and realistic solutions that will help ensure that a safe, healthy, affordable and accessible home is available to everyone in the United States. This section describes the rationale that supports each of the four goals, the challenges to achieving these goals, and the actions that will help to achieve them.

\section{Goal 1: Ensuring Healthy, Safe, Affordable, and Accessible Homes}

\section{Rationale}

People in the United States spend $50 \%$ or more of every day inside their homes (Centers for Disease Control and Prevention and U.S. Department of Housing and Urban Development 2006). A healthy, safe, affordable, and accessible home supports residents' fundamental physical and psychological needs and protects them from illness and injury.

\section{Challenges}

The risk for serious injury, toxic exposures, and illness is increased among those who are least able to find and afford healthy homes. Steps must be taken to eliminate disparities in housing conditions arising from social and economic disadvantage so that people in the United States from all walks of life, ages, and racial and ethnic backgrounds will share the opportunity to have homes that promote and protect health. 


\section{Actions}

For some residential hazards, evidence-based interventions already exist to reduce exposures that cause disease and to prevent injuries. Now these interventions must be made available to all who need them. All levels of society, from single persons and families to government organizations, can begin to implement strategies that will make safe, healthy, affordable, and accessible homes a central component of the nation's public health architecture. Home modifications should be attractive, appropriate for home setting, easy to implement, straightforward to use, affordable, and effective.

\section{For Individuals, Families, Property Owners, and Maintenance Workers}

Persons, families, and property owners can take action to make their homes healthier and more environmentally friendly by improving air quality, safely using various household products, properly using safety devices, adequately supervising children, and abating specific toxic chemicals. Examples of these actions include the following:

- Install, maintain, and consistently use safety devices (e.g., smoke alarms; carbon monoxide alarms; stair gates in homes with young children; grab bars in bathrooms; adequate outside lighting; locks on cabinets used to store medicines, cleaning solutions, automotive supplies, firearms and ammunition, pool chemicals, and pesticides; four-sided isolation fencing with self-closing, self-latching doors around pools).

- Complete a home fall-prevention checklist for homes with older adults (see http://www.cdc.gov/ncipc/duip/fallsmaterial. htm\#BRochures).

- Prepare and practice an emergency fire escape plan (see http://www. firesafety.gov/citizens/escape/index.shtm).

- Prepare shelter-in-place and evacuation plans for weather and other disaster situations (visit http://www.redcross.org/preparedness/ cdc_english/home.asp for more information).

- Set water temperature in your home at $120^{\circ} \mathrm{F}$.

- Routinely check electrical appliances and wiring; replace all worn, old, or damaged appliance cords; do not overload extension cords or wall sockets. 
- Check gas appliances, fireplaces, chimneys, and furnaces yearly and change furnace and air conditioning filters regularly. Never use the oven, stove, charcoal burner, or any unvented combustible heat source to heat the house.

- Do not smoke; enforce smoke-free rules in the home. If you do smoke, do not smoke indoors or around children. For support in quitting smoking, including free quit coaching, a free quit plan, free educational materials, and referrals to local resources, call 1-800-QUIT-NOW (1-800-784-8669) or visit http://www. smokefree.gov.

- Complete a playground safety checklist if you have playground equipment in your yard (see http://www.cpsc.gov/cpscpub/pubs/ pg1.pdf).

- Replace balcony railings spaced greater than 4 inches apart.

- Review the EPA listing of safer cleaning products (see http://www. epa.gov/dfe/pubs/projects/formulat/formpartc.htm\#consumerclean) and select the safest products for the job.

- Keep toxic chemicals, including cleaning products and pesticides, away from children. Choose products with poison-prevention packaging.

- Read product labels and follow directions for use and disposal.

- Consider integrated pest management, including natural, biological, and chemical methods with the least impact on health and the environment.

- Control moisture in the home by sealing cracks, directing downspouts away from the house, installing drains near water heaters and washing machines, and properly installing window air conditioner units.

- Test houses for radon and install a mitigation system if the test result is $4 \mathrm{pCi} / \mathrm{L}$ or higher.

- Include radon mitigation systems or radon-resistant constructionor both-in new home construction located in the midwestern and eastern United States.

- Test houses occupied by children less than 6 years of age for lead and control or eliminate lead hazards. 
- Make sure that infants sleep on their backs on firm sleeping surfaces.

- Use lead-safe work practices when renovating houses built before 1978.

- Contact the local or state health department for assistance remediating lead or radon hazards.

- Leave asbestos material in good condition alone. If the material is damaged or you plan to repair or renovate parts of your home that may contain asbestos material, hire a professional.

- Consider green, environmentally friendly options when selecting home sites, materials, and appliances; when building or renovating; and when using natural resources such as water and energy, like those suggested on the EPA's Green Building Web site (http://www. epa.gov/greenbuilding).

\section{For Community- and Faith-based Organizations}

Community- and faith-based organizations have a critical role in educating at-risk populations about the connection between homes and health and in identifying and addressing home deficiencies. Examples of actions these organizations can take include the following:

- Support adoption of healthy, safe, accessible, affordable, and environmentally friendly homes.

- Provide home-visiting programs with information on supportive housing for people with mental health problems.

- Inform older adults; people with disabilities; and housing and health care professionals about eligibility and coverage in existing home modification services and products (e.g., Medicare, Medicaid, Community Development Block Grants).

- Mediate disputes between tenants and property owners to help stabilize rental properties and prevent evictions.

- Adopt "rapid exit" policies in homeless shelters that ensure that families are quickly released and stay housed thereafter. 


\section{For Health Care Providers and Home-Visiting Programs}

Health care providers and home-visiting programs can promote a more comprehensive and coordinated approach by incorporating healthy housing solutions into their protocols. Examples of these actions include the following:

- Cross-train home-visit staff to identify and address home deficiencies and assist families living in unstable or unsafe home situations or who are at risk for losing their homes.

- Cross-train home-visit staff to assist elderly, individuals with disabilities and their caregivers, and low-income families with fallprevention measures and the installation and maintenance of smoke alarms, carbon monoxide detectors, and other safety devices.

- Identify and adopt appropriate interventions that have proven successful in nonresidential settings, such as ladder safety standards and training and safety programs designed to prevent hand injury or toxic exposure.

\section{For Lenders, Developers, and Home Builders and Inspectors}

Builders, developers, lenders, and mortgage holders are essential to development of a safe, healthy, affordable, and accessible home portfolio. Examples of actions these groups can take include the following:

- Train builders in healthy home construction and building management principles.

- Consider health and safety factors when selecting building sites, construction materials, and building systems.

- Apply smart-growth principles to groups of homes and larger communities.

- Develop lending instruments that consider the financial benefits of healthy homes.

- Dedicate a portion of the Community Reinvestment Act funding to support development of safe and healthy homes.

- Train home inspectors to identify and report on a range of safety and health hazards. 


\section{For Government}

Communities have a variety of policies and laws at their disposal for creating and maintaining healthy homes, including voluntary efforts, regulatory authority, and formal relationships between homes and health professionals. Decisions made at the local, state, and federal levels also can help create homes that are affordable and that improve people's health. Examples of actions government can take include the following:

- Develop and improve upon response plans for extreme weather events (e.g., when use of generators, candles, fireplaces, chain saws, and grills increases) that include education and interventions to prevent dangerous exposures and injuries and incorporate these plans into the health and housing programs in their jurisdictions.

- Enforce housing and sanitary code requirements.

- Conduct regular and comprehensive inspections of subsidized properties and require that these units meet basic safety and sanitary requirements.

- Use housing subsidies to promote mixed-income neighborhoods.

- Use market-based incentives to provide economic compensation to promote healthy homes (e.g., compensating property owners for their costs related to healthy and safe home modifications that benefit society at large).

- Model incentives for healthy homes on existing incentives for energy-efficient products.

- Develop data-sharing and consistent criteria across social service and housing agencies for measuring barriers to permanent homes.

- Emphasize prevention of homelessness and target effectively those at highest risk.

- Integrate housing-related strategies including providing a single entry point for determination of eligibility for services that is colocated with intake centers for other social and aging services.

- Work together across agencies and sectors to provide guidance and technical assistance to support safe, healthy, and environmentally friendly housing options. 


\section{Goal 2: Increase Public Awareness and Promote Health Literacy}

\section{Rationale}

There is a need to improve the public's understanding of the connection between housing and health. Health literacy, including an understanding of the concepts and terms related to healthy homes, helps people take actions that foster healthy and safe homes. Stakeholders, including educators, community-based organizations, and others have key roles in improving housing-health literacy.

\section{Challenges}

Rental property owners, tenants, and single-family homeowners should receive information and tools that could help them make homes safer, healthier, and more environmentally friendly. Because many of these practices must be adopted and maintained by the residents themselves, educational efforts must both provide information and encourage behavior modifications. Educational materials must include guidance about specific steps people can take to reduce health hazards in their homes and strongly promote the benefits of taking such actions. Great care must be taken to develop messages that are inclusive, culturally sensitive, and linguistically appropriate to meet the needs of the socially, economically, and ethnically diverse U.S. population. A broad range of stakeholders should be engaged in crafting these messages.

\section{$\underline{\text { Actions }}$}

\section{For Educators}

Improving healthy homes requires the talents and skills of traditional and nontraditional health and housing partners. Each member of a multidisciplinary healthy homes workforce must understand basic housingrelated health issues. This knowledge base will arm team members with a common, science-based framework for identifying, developing, and implementing healthy housing practices. Examples of actions educators can take include the following:

- Incorporate healthy and environmentally friendly housing education into training programs for public health, environmental health, business administration, and housing professionals; urban planners; architects; and engineers as well as construction, maintenance, pest control, and weatherization experts. 
- Partner with community-based organizations to provide health professional trainees - particularly in nursing education and primary care residency programs - with an enhanced understanding of how housing influences health.

- Use the model healthy housing education programs sponsored by CDC, HUD, and the U.S. Department of Agriculture for training.

- Consider establishing healthy homes fellowship programs to provide on-site training for emerging leaders in the field.

\section{For Community- and Faith-based Organizations}

Community- and faith-based organizations and housing advocacy groups must work together to address both residential needs and economic development, to promote greater knowledge about the ways in which housing affects health issues, and to support leaders' efforts to make informed, evidence-based, and compassionate housing decisions. Examples of actions these groups can take include the following:

- Collaborate with government agencies and academic institutions to ensure that educational materials address community priorities and are appropriate to meet the community's educational needs.

- Develop public awareness campaigns that promote healthy, safe, affordable, accessible, and environmentally friendly homes.

- Promote healthy and safe home modifications and repairs.

\section{Goal 3: Conduct Healthy Homes Research}

\section{Rationale}

Although in the last decade research demonstrating the link between specific housing conditions and health has matured, significant knowledge gaps remain. Addressing these gaps will require research that links housing conditions with specific health outcomes while accounting for personal, home unit, neighborhood, and community-level factors and the impact of disparate access to safe, healthy, affordable, and accessible homes. Research is also necessary to evaluate the effectiveness of comprehensive housing improvements, regulatory policies, and voluntary initiatives. Unless healthy housing is carefully studied in methodologically appropriate ways, the risk remains that families, property owners, and government agencies responsible for providing housing assistance will undertake expensive but ineffective interventions. Progress toward promoting healthy homes also depends on 
demonstrating that healthy homes is feasible, cost-efficient, and beneficial (Proscio 2004).

\section{Challenges}

To advance public health actions that will have a significant impact on health, the nation needs a more holistic understanding of how housing affects people's health (U.S. Department of Health and Human Services 2005a). Such research requires a broad approach involving many disciplines such as fire prevention, safety science, engineering, psychology, home design, epidemiology, exposure assessment, medicine, risk management, environmental science, and public policy science.

\section{$\underline{\text { Actions }}$}

For Government, Academic and Research Organizations and Scientists

Government agencies, other research organizations, and scientists should develop and support a portfolio of rigorous healthy homes research. They need to build interdisciplinary teams that are well versed in the conduct of community-based research and the use of sophisticated statistical techniques. Examples of actions these agencies and organizations can take include the following:

- Conduct research to identify additional housing factors that can harm, or promote and protect people's health.

- Promote efforts to understand the causal sequences of events leading to specific injuries.

- Conduct research to advance our understanding of building practices and health and safety measures that improve resident health, such as the health consequences of energy-efficient buildings and smart technologies.

- Conduct research to determine safe levels of household chemicals for different types of housing and different subpopulations.

- Determine the impact of related, simultaneously implemented housing remediation on multiple health outcomes.

- Improve the design and statistical methods used to evaluate healthy homes intervention studies.

- Develop and implement a healthy homes monitoring and tracking system. 
- Conduct studies that determine what proportion of illness and injury should be ascribed to unhealthy homes.

- Describe the biologic and other mechanisms that link the housing environment and mental health.

- Conduct research that identifies beneficial and detrimental behavioral responses to emergencies such as residential fires, masstrauma events, and weather-related catastrophes.

- Quantify the costs of suboptimal housing and the costs and benefits of various strategies to make homes healthier.

- Test intervention strategies thought to improve health.

- Create academic programs to train future workers in the healthy homes field.

\section{Goal 4: Translate Research into Practice and Policy}

\section{Rationale}

To improve human health, research discoveries must be translated into practical applications. Both basic research, in which scientists study disease at a molecular or cellular level, and applied research, in which scientists study whether proposed interventions are effective, need to be brought to the reality of people's lives.

\section{Challenges}

The barriers between the scientific research community and the sectors of society that can benefit most directly from their work as well as the everincreasing complexities involved in conducting scientific research make it difficult to move new knowledge from research to action in a timely way. The barriers and complexities also slow down information from the field that would help stimulate new research questions. Opportunities for communication between scientists and those in the field are few: limited rewards exist for scientists who pursue translation research and training opportunities are scarce. These challenges limit professional interest in the field and hamper the conduct of translation research at a time when it should be expanding. 


\section{Actions}

Once the best practices for prevention are identified, successfully translating them into actual practice should take two approaches: an approach that focuses on constructing and maintaining housing in ways that promote and protect health and an approach that addresses changing individual and community behaviors. Open collaboration among professionals involved in constructing and maintaining homes and scientists, government agencies, and housing advocacy organizations would ensure that each group has upto-date information and access to resources.

\section{For Government, Academic, and Research Organizations and $\underline{\text { Scientists }}$}

Government, academic, and research and other organizations that fund scientific research should ensure that activities to translate scientific findings into practice are supported in their sponsored research programs. Academic and research institutions and individual scientists should provide training and pursue opportunities in research translation; examples include the following:

- Develop and implement mechanisms for updating recommendations and communicating them to housing agencies and professionals involved in constructing and maintaining homes.

- Develop and implement mechanisms to accelerate the transfer of research findings into home-based health care and social services, housing programs, and other service-delivery systems.

- Use evidence-based interventions to develop or support a program to certify houses and homes-related consumer products as healthy and safe.

- Communicate research findings to the public, health care providers, and policy makers that clearly describe behaviors and actions that promote healthy homes.

- Communicate research findings through a broad range of media and products with the intention of widespread dissemination and adoption. 


\section{Section 6 Conclusions}

With this Call to Action To Promote Healthy Homes, the Surgeon General emphasizes that health must begin at home. To improve the nation's overall health, we must improve the health of the nation's homes and ensure that safe, healthy, affordable, accessible, and environmentally friendly homes are available to everyone in the United States. This is no small task; it will require dedication, ingenuity, skill, and the concerted effort on the parts of many people in many sectors. Several key participants have been identified and are enthusiastically engaged. The actions outlined in this document are the next steps. Strengthening and widening these efforts is an urgent matter. Ensuring that the nation's homes are safe, healthy, affordable, accessible, and environmentally friendly will have a direct, immediate, and measurable affect on the health of the nation. 


\section{References}

Ahrens M. 2004. US experience with smoke alarms and other fire detection/ alarm equipment. Quincy, MA: National Fire Protection Association. Available at http://fire.state.nv.us [accessed 2007 August 14].

Ahrens M. 2007. U.S. experience with smoke alarms and other fire detection/alarm equipment. Quincy, MA: National Fire Protection Association. Available at http://www.nfpa.org/itemDetail.asp?categoryID= 521\&itemID=18245\&URL=Research\%20\&\%20Reports/Fire\%20reports/ Fire\%20protection\%20systems [accessed 2008 August 5].

Akinbami LJ, Schoendorf KC. 2002. Trends in childhood asthma: prevalence, health care utilization, and mortality. Pediatrics 110:315-22.

Anderson AD, Heryford AG, Sarisky JP, Higgins C, Monroe SS, Beard RS, et al. 2003. A waterborne outbreak of Norwalk-like virus among snowmobilers-Wyoming, 2001. J Infect Dis 187:303-6.

Arbes SJ, Cohn RD, Yin M, Muilenberg ML, Burge HA, Friedman W, et al. 2003. House dust mite allergen in US beds: results from the first National Survey of Lead and Allergens in Housing. J Allergy Clin Immunol 111(2):408-14.

Ballesteros MF, Kresnow MJ. 2007. Prevalence of residential smoke alarms and fire escape plans in the U.S.: results from the Second Injury Control and Risk Survey (ICARIS-2). Publ Health Rep 122:224-31.

Barlow B, Niemirska M, Gandhi RP, Leblanc W. 1983. Ten years of experience with falls from a height in children. J Pediatr Surg 18:509-11.

Baum A, Valins S. 1979. Architectural mediation of residential density and control: crowding and the regulation of social contact. In: Berkowitz L, editor. Advances in experimental social psychology, vol. 12. New York: Academic Press, pp 131-75.

Bell PA, Greene TC, Fisher JD, Baum A. 2001. High density and crowding. In: Environmental psychology, 5th edition. Belmont, CA: Thomson Wadsworth. p. 293-332.

Berglund B, Lindvall T, Schwela DH, editors. 1999. Guidelines for community noise. Geneva: World Health Organization. 
Bingenheimer JB, Raudenbush SW. 2004. Statistical and substantive inferences in public health: Issues in the application of multilevel models. Annu Rev Publ Health 25:53-77.

Bornehag C-G, Sundell J, Sigsgaard T. 2004. Dampness in buildings and health $(\mathrm{DBH})$ : report from an ongoing epidemiological investigation on the association between indoor environmental factors and health effects among children in Sweden. Indoor Air 14(suppl 7):59-66.

Brenner RA, Trumble AC, Smith GS, Kessler EP, Overpeck MD. 2001. Where children drown, United States, 1995. Pediatrics 108(1):85-9.

Brown MJ, Gardner J, Sargent J, Swartz K, Hu H, Timperi R. 2001. Effectiveness of housing policies in reducing children's lead exposure. Am J Public Health 91:621-4.

Brown MJ. 2002. Costs and benefits of enforcing housing policies to prevent childhood lead poisoning. Med Decision Making 22:482-92.

Buckner JC. 2008. Understanding the impact of homelessness on children: challenges and future research directions. Am Behav Sci 51:721-36.

Buka SL, Brennan RT, Rich-Edwards JW, Raudenbush SW, Earls F. 2003. Neighborhood support and the birth weight of urban infants. Am J Epidemiol 157:1-8.

Burt MR, Aron LY, Lee E Valente J. 2001. Helping America's homeless: emergency shelter or affordable housing? Washington, DC: The Urban Institute Press.

Burt MR, Pearson C, Montgomery AE. 2007. Community-wide strategies for preventing homelessness: recent evidence. J Prim Prev 28:213-28.

Casarett and Doull eds. 1991. Toxicology: the basic science of poisons. New York: Pergamon Press.

Casteel C, Runyan CW. 2004. Leading causes of unintentional home injury in high-risk age groups. In: Runyan CW, Casteel C, editors. The state of home safety in America. 2nd edition. Washington, DC: Home Safety Council. p. 61-8.

Centers for Disease Control and Prevention. 1995. A survey of the quality of water drawn from domestic wells in nine Midwest states. Atlanta: U.S. Department of Health and Human Services.

Centers for Disease Control and Prevention. 2005a. Blood lead levelsUnited States, 1999-2002. MMWR 54:513-6. 
Centers for Disease Control and Prevention. 2005b. Annual smokingattributable mortality, years of potential life lost and productivity lossesUnited States 1997-2001. MMWR 54:625-8.

Centers for Disease Control and Prevention. 2005c. Unintentional non-fire-related carbon monoxide exposures-United States, 2001-2003. MMWR 54(2):36-9.

Centers for Disease Control and Prevention. 2005d. Preventing Lead Poisoning In Young Children. Atlanta: U.S. Department of Health and Human Services.

Centers for Disease Control and Prevention. 2006. Web-based Injury Statistics Query and Reporting System (WISQARS). Atlanta: U.S. Department of Health and Human Services. Available at http:// www.cdc. gov/ncipc/wisqars [accessed 2008 December 2].

Centers for Disease Control and Prevention. 2007a. Carbon monoxide exposures-United States, 1999-2004. MMWR 56(50):1309-12.

Centers for Disease Control and Prevention. 2007b. National Vital Statistics System. 2001 to 2005 nonfatal injury data. Hyattsville, MD: U.S. Department of Health and Human Services.

Centers for Disease Control and Prevention. 2008. Unintentional, non-firerelated, nonfatal carbon monoxide exposures-United States, 2004-2006. MMWR 57(33):896-9.

Centers for Disease Control and Prevention. undated. Private ground water wells. Atlanta: U.S. Department of Health and Human Services. Available at http://www.cdc.gov/ncidod/dpd/healthywater/privatewell.htm [accessed 2009 April 15].

Centers for Disease Control and Prevention and U.S. Department of Housing and Urban Development. 2006. Healthy housing reference manual. Atlanta: U.S. Department of Health and Human Services. Available at http://www.cdc.gov/nceh/publications/books/housing/housing. htm [accessed 2008 July 27].

Centers for Disease Control and Prevention and U.S. Department of Housing and Urban Development. 2008. Healthy housing inspection manual. Atlanta: U.S. Department of Health and Human Services. Available at http://www.cdc.gov/nceh/publications/books/ inspectionmanual/ [accessed 2008 July 27]. 
Chanda SM, Pope CN. 1996. Neurochemical and neurobehavioral effects of repeated gestational exposure to chlorpyrifos in maternal and developing rats. Pharmacol Biochem Behav 53:771-6.

Chevrier J, Eskenzi B, Bradman A, Fenster L, Barr D. 2007. Association between prenatal exposure to polychlorinated biphenyls and neonatal thyroid-stimulating hormone levels in a Mexican-American populations, Salinas Valley, California. Environ Health Perpect 115:1490-6.

Cohn RD, Arbes SJ Jr, Yin M, Jaramillo R, Zeldin DC. 2004. National prevalence and exposure risk for mouse allergen in US households. J Allergy Clin Immunol 113(6):1167-71.

Cohn RD, Arbes SJ Jr, Jaramillo R, Reid LH, Zeldin DC. 2006. National prevalence and exposure risk for cockroach allergen in U.S. households. Environ Health Perspect 114:522-6.

Colford JM, Roy SL, Beach MJ, Hightower A, Shaw SE, Wade TJ. 2006. A review of household drinking water intervention trials and an approach to the estimation of endemic waterborne gastroenteritis in the United States. J Water Health 4(suppl 2):71-88.

Committee on Health Risks of Exposure to Radiation (BEIR VI). 1999. Health effects of exposure to radon. Washington, DC: The National Academies Press.

Committee on Injury, Violence, and Poison Prevention. 2003. Policy statement: prevention of drowning in infants, children, and adolescents. Pediatrics 112: 440-5.

Corso P, Finkelstein E, Miller T, Fiebelkorn I, Zaloshnja E. 2006. Incidence and lifetime costs of injuries in the United States. Inj Prev 12:212-18.

Cummins SK, Jackson RJ. 2001. The built environment and children's health. Pediatr Clin N Am 48:1241-52.

Daley WR, Smith A, Paz-Argandona E, Malilay J, McGeehin M. 2000. An outbreak of carbon monoxide poisoning after a major ice storm in Maine. J Emerg Med 18(1):87-93.

Desor JA. 1972. Toward a psychological theory of crowding. J Pers Soc Psychol 21:79-83.

Dunn JR, Walker JD, Graham J, Weiss CB. 2004. Gender differences in the relationship between housing, socioeconomic status, and self-reported health status. Rev Environ Health 19(3-4):177-95. 
Ernst A, Zibrak JD. 1998. Carbon monoxide poisoning. N Engl J Med 339:1603-8.

Evans GW, Lepore SJ, Schroeder A. 1996. The role of interior design elements in human responses to crowding. J Pers Soc Psychol 70:41-6.

Evans GW, Lepore SJ, Allen KM. 2000. Cross-cultural differences in tolerance for crowding: fact or fiction? J Pers Soc Psychol 79:204-10.

Evans GW, Saegert S, Harris R. 2001. Residential density and psychological health among children in low-income families. Environ Behav 33:165-80.

Evans GW, Marcynyszyn LA. 2004. Environmental justice, cumulative environmental risk and health among low- and middle-income children in upstate New York. Am J Public Health 96:1942-4.

Foarde KK. 1998. Proper use of biocides in HVAC systems. National Air Duct Cleaners 9th Annual Meeting and Exposition, 1998. Research Triangle Park, NC: Research Triangle Institute.

Field RW, Steck DJ, Smith BJ, Brus CP, Fisher EL, Neuberger JS, et al. 2000. Residential radon gas exposure and lung cancer: the Iowa radon lung cancer study. Am J Epidemiol 151:1091-102.

Flores G, Tomany-Korman SC, Olson L. 2005. Does disadvantage start at home? Racial and ethnic disparities in health-related early childhood home routines and safety practices. Arch Pediatr Adolesc Med 159:158-65.

Frumkin H, Frank L, Jackson R. 2004. Urban sprawl and public health: designing, planning, and building for healthier communities. Washington, DC: Island Press.

Frumkin H, Samet JM. 2001. Radon. CA Cancer J Clin 51;337-44.

Gielen AC, Wilson MEH, Faden RR, Wissow L, Harvilchuck JD. 1995. In-home injury prevention practices for infants and toddlers: the role of parental beliefs, barriers, and housing quality. Health Educ Q 22:85-95.

Golden RN, Gaynes BN, Ekstrom RD, Hamer RM, Jacobsen FM, Suppes T, et al. 2005. The efficacy of light therapy in the treatment of mood disorders: a review and meta-analysis of the evidence. Am J Psychiatr 162:656-62.

Greer FR, Shannon M, Committee on Nutrition, Committee on Environmental Health. 2005. Infant methemoglobinemia: the role of dietary nitrate in food and water. Pediatrics 116(3):784-6. 
Grosse SD, Matte TD, Schwartz J, Jackson RJ. 2002. Economic gains resulting from the reduction in children's exposure to lead in the United States. Environ Health Perspect 110:563-9.

Hall JR. 2001. Burns, toxic gases, and other hazards associated with fires: deaths and injuries in fire and non-fire situations. Quincy, MA: National Fire Protection Association.

Hannon L, Shai D. 2003. The truly disadvantaged and the structural covariates of fire death rates. Soc Sci J 40(1):129-36.

Hendershot G. 2004. Building design is leading barrier to community participation. Washington, DC: National Organization on Disability; 2004. Available at http://www.nod.org [accessed 2007 August 14].

Institute of Medicine. 2000. Clearing the air: asthma and indoor air exposures. Washington, DC: The National Academies Press.

Institute of Medicine. 2004. Damp indoor spaces and health. Washington, DC: The National Academies Press.

Institute of Medicine. 2005. Ethical considerations for research on housingrelated health hazards involving children. Washington, DC: The National Academies Press.

Istre GR, McCoy MA, Osborn L, Barnard JJ, Bolten A. 2001. Deaths and injuries from house fires. N Engl J Med 344:1911-6.

Jacobs DE. 2006. A qualitative review of housing hazard identification protocols in the United States. Environ Res 102:13-21.

Jacobs DE, Clickner RP, Zhou JY, Viet SM, Marker DA, Rogers JW, et al. 2002. The prevalence of lead-based paint hazards in U.S. housing. Environ Health Perspect 110:A599-A606.

Jacobs DE, Kelly T, Sobolewski J. 2007. Linking public health, housing and indoor environmental policy: successes and challenges at the local and federal agencies in the United States. Environ Health Perspect 115:976-82. Jargowsky PA. 1997. Poverty and place: ghettos, barrios, and the American city. New York: Russell Sage Foundation.

Joint Center for Housing Studies of Harvard University. 2004. The state of the nation's housing: 2004. Cambridge, MA: President and Fellows of Harvard College. Available at http://www.jchs.harvard.edu/publications/ markets/son2004.pdf [accessed 2007 August 17]. 
Joint Center for Housing Studies of Harvard University. 2008. The state of the nation's housing: 2008. Cambridge, MA: President and Fellows of Harvard College. Available at http://www.jchs.harvard.edu/publications/ markets/son2008.pdf [accessed 2008 June 29].

Jones RL, Homa DM, Meyer PA, Brody DJ, Caldwell KL Pirkle JL, et al. 2009. Trends in blood lead levels and blood lead testing among U.S. children aged 1 to 5 years: 1998-2004. Pediatrics 123(3):e376-85.

Karter MJ. 2007. Fire loss in the United States during 2006. Quincy, MA: National Fire Protection Association.

Kattan M, Stearns SC, Crain EF, Stout JW, Gergen PJ, Evans R 3rd, et al. 2005. Cost effectiveness of home-based environmental intervention for inner-city children with asthma. J Allergy Clin Immunol 116:1058-63.

Katz LF, Kling JR, Liebman JB. 2001. Moving to opportunity in Boston: early results of a randomized mobility experiment. Q J Econ 116(2):60754.

Klitzman S, Caravanos J, Belanoff C, Rothenberg L. 2005. A multihazard, multistrategy approach to home remediation: results of a pilot study. Environ Res 99:294-306.

Krieger J, Higgins DL. 2002. Housing and health: time again for public health action. Am J Public Health 92:758-68.

Krieger JW, Takaro TK, Song L, Weaver M. 2005. The Seattle-King County healthy homes project: a randomized controlled trial of a community health worker intervention to decrease exposure to indoor asthma triggers. Am J Public Health 95:642-59.

Kripke KF. 1998. Light treatment for nonseasonal depression: speed, efficacy and combined treatment. J Affec Disord 49:109-17.

Leaver CA, Bargh G, Dunn JR, Hwang SW. 2007. The effects of housing status on health-related outcomes in people living with HIV: a systematic review of the literature. AIDS Behav 11(suppl 6):85-100.

Lepore SJ, Evans GW, Schneider ML. 1992. Role of control and social support in explaining the stress of hassles and crowding. Environ Behav 24:795-811.

Leventhal T, Brooks-Gunn J. 2003. Moving to opportunity: An experimental study of neighborhood effects on mental health. Am J Public Health 93(9):1576-82. 
Levin R, Brown MJ, Kashtock ME, Jacobs DE, Whelan EA, Rodman J, 2008. Children's lead exposures in the United States, 2008: implications for primary lead poisoning prevention strategies. Environ Health Perspect 116(10):1285-93.

Lu C, Knutson DE, Fisker-Andersen J, Fenske RA. 2001. Biological monitoring survey of organophosphorous pesticide exposure among preschool children in the Seattle metropolitan area. Environ Health Perspect 109:299-303.

MacKay M. 2003. Playground injuries. Inj Prev 9(3):194-6.

Marshall SW, Runyan CW, Yang J, Coyne-Beasley T, Waller AE, Johnson RM, et al. 2005. Prevalence of selected risk and protective factors for falls in the home. Am J Prev Med 28:95-101.

Matsui EC, Wood RA, Rand C, Kanchanaraksa S, Swartz L, CurtinBrosnan J, et al. 2003. Cockroach allergen exposure and sensitization in suburban middle-class children with asthma. J Allerg Clin Immunol 112:87-92.

Matte TD, Jacobs DE. 2000. Housing and health—current issues and implications for research and programs. J Urban Health 77:7-25.

McDonald J. 2002. Nursery product-related deaths and injuries to children under age 5. Washington, DC: U.S. Consumer Product Safety Commission. Available at http://www.cpsc.gov/LIBRARY/nursery05.pdf [accessed 2009 April 16].

McDonald EM, Gielen AC. 2006. House fires and other intentional home injuries. In: Gielen AC, Sleet DA, DiClemente R, editors. Injury and violence prevention: behavioral science theories, methods and applications. San Francisco, CA: Jossey-Bass. p. 274-96.

McDonald EM, Girasek DC, Gielen AC. 2006. Home injuries. In: Liller $\mathrm{KD}$, editor. Injury prevention for children and adolescents: research, practice, and advocacy. Washington, DC: American Public Health Association. p. 125-30.

McLoughlin E, Marchone M, Hanger L, German PS, Baker SP. 1985. Smoke detector legislation: its effect on owner-occupied homes. Am J Public Health 75(8):858-62. 
Messner M, Shaw S, Regli S, Rotert K, Blank V, Soller J. 2006. An approach for developing a national estimate of waterborne disease due to drinking water and a national estimate model application. J Water Health 4(suppl 2):201-40.)

Miller M, Azrael D, Hemenway D, Vriniotis M. 2005. Firearm storage practices and rates of unintentional firearm deaths in the United States. Accid Anal Prev 37:661-7.

Moritz AR, Henriques FC. 1947. Studies of thermal injury: the relative importance of time and surface temperature in the causation of cutaneous burns. Am J Pathol 23:695-720.

Mudarri D, Fisk WJ. 2007. Public health and economic impact of dampness and mold. Indoor Air 17;226-35.

Nagaraja J, Menkedick J, Phelan KJ, Ashley P, Zhang X, Lanphear BP. 2005. Deaths from residential injuries in US children and adolescents, 1985-1997. Pediatrics 116:454-61.

National Alliance to End Homelessness. 2007. Policy guide. Washington, DC: National Alliance to End Homelessness.

National Center for Healthy Housing. 2008. Boston One Touch: action steps for healthier and greener homes for Boston families. Columbia, MD: National Center for Healthy Housing.

National Institute of Building Sciences. 2005. IEQ Indoor environmental quality. Washington, DC: National Institute of Building Sciences. Available at http://ieq.nibs.org/ieq_project.pdf [accessed 2009 February 18].

Naughton MP, Henderson A, Mirabellin MC, Kaiser R, Wilhelm JL, Kieszak SM, et al. 2002. Heat-related mortality during a 1999 heat wave in Chicago. Am J Prev Med 22:221-7.

New York City Department of Health. 2000. Guidelines on assessment and remediation of fungi in indoor environments. New York City Bureau of Environmental and Occupational Disease Epidemiology.

Orr L, Feins JD, Jacob R, Beecroft E. 2003. Moving to opportunity: interim impacts evaluation. Washington, DC: U.S. Department of Housing and Urban Development. Available at http://www.huduser.org/Publications/ pdf/MTOFullReport.pdf [accessed 2009 April 16].

Passchier-Vermeer W, Passchier WF. 2000. Noise exposure and public health. Environ Health Perspect 108(suppl 1):123-31. 
Pirkle JL, Bernert JT, Caudill SP, Sosnoff CS, Pechacek TF. 2006. Trends in the exposure of nonsmokers in the U.S. population to secondhand smoke: 1988-2002. Environ Health Perspect 114:853-8.

Proscio T. 2004. Healthy housing, healthy families: toward a national agenda for affordable healthy homes. Columbia, MD: National Center for Healthy Housing.

Quan L, Bennett EE, Branche CM. 2007. Interventions to prevent drowning. In: Doll LS, Bonzo SE, Sleet DA, Mercy JA, Haas EN, editors. Handbook of injury and violence prevention. New York: Springer. p. 8196.

Raub JA, Mathieu-Nolf M, Hampson NB. 2000. Carbon monoxide poisoning — a public health perspective. Toxicology 145:1-14.

Rauchschwalbe R, Mann NC. 1997. Pediatric window-cord strangulations in the United States, 1981-1995. JAMA 277(21):1696-8.

Regoeczi WC. 2003. When context matters: a multilevel analysis of household and neighborhood crowding on aggression and withdrawal. J Environ Psychol 23:457-70.

Rice D, Barone S Jr. 2000. Critical periods of vulnerability for the developing nervous system: evidence from humans and animal models. Environ Health Perspect 108(suppl 3):511-33.

Rog DL, McCombs-Thornton DL, Gilbert-Mongelli AM, Brito MC, Holupka DS. 1995. Implementation of the homeless families program:

2. Characteristics, strengths and needs of participant families. Am J Orthopsychiatry 64:514-28.

Rubenstein LZ, Stevens JA, Scott V. 2007. Interventions to prevent falls among older adults. In: Doll LS, Bonzo SE, Sleet DA, Mercy JA, Haas EN, editors. Handbook of injury and violence prevention. New York: Springer. p. $37-53$.

Runyan CW, Casteel C, Perkis D, Black C, Marshall SW, Johnson RM, et al. 2005a. Unintentional injuries in the home in the United States, part I: mortality. Am J Prev Med 28:73-9.

Runyan CW, Perkis D, Marshall SW, Johnson RM, Coyne-Beasley T, Waller AE, et al. 2005b. Unintentional injuries in the home in the United States, part II: morbidity. Am J Prev Med 28:80-7. 
Salam MT, Li Y-F, Langholz B, Gilliland FD, Children's Health Study. 2004. Early-life environmental risk factors for asthma: findings from the Children's Health Study. Environ Health Perspect 112:760-765.

Saluja G, Brenner RA, Trumble AC, Smith GS, Schroeder T, Cox C. 2006. Swimming pool drownings among US residents aged 5-24 years: understanding racial/ethnic disparities. Am J Public Health 96(4):728-33.

Savinar J. 1975. The effect of ceiling height on personal space. ManEnvironment Systems 5:321-4.

Sharfstein J, Sandel M, editors. 1998. Not safe at home: how America's housing crisis threatens the health of its children. Boston: Boston Medical Center.

Shenassa ED, Stubbendick A, Brown MJ. 2004. Social disparities in housing and related pediatric injury: a multilevel study. Am J Public Health 94(4):633-9.

Shenassa ED, Daskalakis D, Liebhaber A, Braubach M, Brown MJ. 2007. Dampness and mold in the home and depression: an examination of moldrelated illness and perceived control of one's home as possible depression pathways. Am J Public Health 97:1893-9.

Shinn M, Weitzman BC, Stojanovic D, Knickman JR, Jimenez I, Duchon L, et al. 1998. Predictors of homelessness among families in New York City: from shelter request to housing stability. Am J Public Health 88:1651-7.

Smith CL. 1993. Smoke detector operability survey-report on findings. Bethesda, MD: U.S. Consumer Product Safety Commission.

Staunton CE, Frumkin H, Dannenberg AL. 2007. Changing the built environment to prevent injury. In: Doll LS, Bonzo SE, Sleet DA, Mercy JA, Haas EN, editors. Handbook of injury and violence prevention. New York: Springer. p. 257-76.

Stojanovic D, Weitzman BC, Shinn M, Labay LE, Williams NP. 1999. Tracing the path out of homelessness: the housing patterns of families after exiting shelter. J Commun Psychol 27:199-208.

Thompson NJ, Waterman MB, Sleet DA. 2004. Using behavioral science to improve fire escape behaviors in response to a smoke alarm. J Burn Care Rehabil 25(2):179-88.

Ulrich RS. 1984. View through a window may influence recovery from surgery. Science 224:420-1. 
U.S. Census Bureau. 2006. Current housing reports, series H150/05, American Housing Survey for the United States: 2005. Washington, DC: U.S. Government Printing Office.

U.S. Consumer Product Safety Commission. undated a. National Electronic Injury Surveillance System (NEISS) on-line. Washington, DC: U.S. Consumer Product Safety Commission. Available at http://www.cpsc.gov/ LIBRARY/neiss.html [accessed 2008 July 21].

U.S. Consumer Product Safety Commission. undated b. How to plan for the unexpected: preventing child drownings. Washington, DC: U.S. Consumer Product Safety Commission. Publication no. 359. Available at http://www.cpsc.gov/cpscpub/pubs/359.pdf.

U.S. Consumer Product Safety Commission. undated c. Children can strangle in window covering cords. Washington, DC: U.S. Consumer Product Safety Commission. Available at http://www.cpsc.gov/CPSCPUB/ PUBS/cords.html [accessed 2008 July 22].

U.S. Department of Energy. 2006. 2006 buildings energy data book. Washington, DC: U.S. Government Printing Office.

U.S. Department of Health and Human Services. 2005a. Report of the Surgeon General's Workshop on Healthy Indoor Environment, January 12-13, 2005. Washington, DC: U.S. Department of Health and Human Services. Available at http://www.surgeongeneral.gov/topics/indoorenv/ [accessed 2007 August 17].

U.S. Department of Health and Human Services. 2005b. Surgeon General releases national health advisory on radon. Washington, DC: U.S. Department of Health and Human Services. Available at http://www. surgeongeneral.gov/pressreleases/sg01132005.html [accessed 2007 August 17].

U.S. Department of Health and Human Services. 2006. The health consequences of involuntary exposure to tobacco smoke: a report of the Surgeon General. Atlanta, GA: Centers for Disease Control and Prevention.

U.S. Department of Housing and Urban Development. 1995. Guidelines for the evaluation and control of lead-based paint hazards in housing. Washington, DC: U.S. Department of Housing and Urban Development. Available at http://www.hud.gov/offices/lead/lbp/hudguidelines [accessed 2007 August 17]. 
U.S. Department of Housing and Urban Development. 2000. Strategic plan FY2000-FY2006. Washington, DC: U.S. Department of Housing and Urban Development.

U.S. Department of Housing and Urban Development. 2007. Affordable housing needs 2005: report to Congress. Washington, DC: U.S.

Department of Housing and Urban Development. Available at: http://www. huduser.org/publications/affhsg/affhsgneeds.html [accessed 2008 August 5].

U.S. Environmental Protection Agency. 1998. Children's vulnerability to toxic substances in the environment. Washington, DC: U.S. Environmental Protection Agency.

U.S. Environmental Protection Agency. 2001. Mold remediation in schools and commercial buildings. EPA 402-K-01-001. Washington, DC: U.S. Environmental Protection Agency. Available at http://www.epa.gov/mold/ mold_remediation.html [accessed 2008 July 30].

U.S. Environmental Protection Agency. 2003. EPA Assessment of risks from radon in homes. EPA 402-R-03-003. Washington, DC: U.S. Environmental Protection Agency. Available at http://www.epa.gov/radon/ pdfs/402-r-03-003.pdf [accessed 2008 June 9].

U.S. Environmental Protection Agency. 2004. Pesticides industry sales and usage: 2000 and 2001 market estimates. Washington, DC: U.S. Environmental Protection Agency. Available at http://epa.gov/oppbead1/ pestsales/01 pestsales/market_estimates2001.pdf [accessed 2008 June 12].

U.S. Environmental Protection Agency. 2007. Important exposure factors for children: an analysis of laboratory and observational field data characterizing cumulative exposure to pesticides. EPA 600-R-07-013. Washington, DC: U.S. Environmental Protection Agency. Available at http://www.epa.gov/nerl/research/data/exposure-factors.pdf [accessed 2008 August 1].

U.S. Environmental Protection Agency. undated a. Radon health risks. Washington, DC: U.S. Environmental Protection Agency. Available at http://www.epa.gov/radon/healthrisks.html [accessed 2007 July 26].

U.S. Environmental Protection Agency. undated b. Map of radon zones. Washington, DC. U.S. Environmental Protection Agency. Available at http://www.epa.gov/radon/zonemap.html [accessed 2008 June 9].

U.S. Environmental Protection Agency. undated c. Private drinking water wells. Washington, DC: U.S. Environmental Protection Agency. Available at http://www.epa.gov/safewater/privatewells/index2.html [accessed 2007 July 26]. 
U.S. Environmental Protection Agency. undated d. Household hazardous waste. Washington, DC. U.S. Environmental Protection Agency. Available at http://www.epa.gov/garbage/hhw.html [accessed 2008 August 15].

U.S. Fire Administration. 2006. Fire and the older adult. FA-300.

Washington, DC: U.S. Government Printing Office. Available at: http:// www.usfa.dhs.gov/downloads/pdf/publications/fa-300.pdf [accessed 2009 April 16].

von Hoffman A. 1998. The origins of American housing reform. Providence, RI: Harvard University Joint Center for Housing Studies.

Warda LJ, Ballesteros MF. 2007. Residential fire injury prevention. In: Doll LS, Bonzo SE, Sleet DA, Mercy JA, Haas EN, editors. Handbook of injury and violence prevention. New York: Springer. p. 97-115.

Warda L, Tenenbein M, Moffatt MEK. 1999. House fire injury prevention update. Part I: a review of risk factors for fatal and non-fatal house fire injury. Inj Prev 5:145-50.

Washington State Department of Health. 1998. 1997 annual report, Pesticide Incident Reporting and Tracking Review Panel. Olympia, WA: Washington State Department of Health.

Watson WA, Litovitz TL, Klein-Schwartz W, Rodgers GC Jr, Youniss J, Reid N, et al. 2004. 2003 Annual report of the American Association of Poison Control Centers Toxic Exposures Surveillance System. Am J Emerg Med 22(5):335-404.

Wells NM. 2000. At home with nature: effects of "greenness" on children's cognitive functioning. Environ Behav 32:775-95.

Williams MK, Barr DB, Camann DE, Cruz LA, Carlton EJ, Borjas M, et al. 2006. An intervention to reduce residential insecticide exposure during pregnancy among an inner city cohort. Environ Health Perspect 114:1684-9.

World Meteorological Organization. undated. Natural hazards. Available at http://www.wmo.int/pages/themes/hazards/index_en.html [accessed 2009 April 16].

Zaloshnja E, Miller TR, Lawrence BA, Romano E. 2005. The costs of unintentional home injuries. Am J Prev Med 28(1):88-94. 


\section{Acknowledgments}

\section{CONTRIBUTING EDITORS}

Steven K. Galson, M.D., M.P.H.

Rear Admiral, United States Public Health Service

Acting Surgeon General

Office of the Surgeon General

Department of Health and Human Services

Robert C. Williams, P.E., D.E.E.

Rear Admiral, United States Public Health Service

Acting Deputy Surgeon General

Office of the Surgeon General

Department of Health and Human Services

Carol A. Romano, Ph.D., R.N., F.A.A.N.

Rear Admiral, United States Public Health Service

Acting Chief of Staff

Office of the Surgeon General

Department of Health and Human Services

Kenneth P. Moritsugu, M.D., M.P.H.,

Rear Admiral, United States Public Health Service (Ret.)

Former, Acting Surgeon General

Office of the Surgeon General

Department of Health and Human Services

Mary Beth Bigley, Dr.P.H., M.S.N., A.N.P.

Acting Director of Science and Communications

Office of the Surgeon General

Department of Health and Human Services

Joel Nelson, M.S.W., M.P.H.

Lieutenant, United States Public Health Service

Special Assistant to the Deputy Surgeon General

Office of the Surgeon General

Department of Health and Human Services

Peter D. Rumm, M.D., M.P.H.

Deputy Director, Division of General, Federal Drug Administration

Office of the Surgeon General

Department of Health and Human Services 
Karen A. Near, M.D., M.S.

Former Senior Science Advisor

Office of the Surgeon General

Department of Health and Human Services

Catherine Wisner, Ph.D., F.N.P.

Former Senior Health Fellow

Office of the Surgeon General

Department of Health and Human Services

\section{Mary Jean Brown, Sc.D., R.N.}

Chief, Lead Poisoning Prevention Branch

Division of Emergency and Environmental Health Services

National Center for Environmental Health

Centers for Disease Control and Prevention

\section{Karin Mack, Ph.D.}

Division of Unintentional Injury Prevention

National Center for Injury Prevention and Control

Centers for Disease Control and Prevention

Pamela Meyer, Ph.D.

Team Leader

Healthy Homes Goal Team

Coordinating Center for Environmental Health and Injury Prevention

Centers for Disease Control and Prevention

Sven E. Rodenbeck, Sc.D., P.E., B.C.E.E.

Captain, United States Public Health Service

Deputy Branch Chief

Agency for Toxic Substances and Disease Registry

\section{Peter A. Briss, M.D., M.P.H.}

Captain, United States Public Health Service

Science Officer

Coordinating Center for Environmental Health and Injury Prevention Centers for Disease Control and Prevention

\section{Howard Frumkin, M.D., Dr.P.H.}

Director, National Center for Environmental Health/

Agency for Toxic Substances and Disease Registry

Centers for Disease Control and Prevention 


\section{Tom Sinks, Ph.D.}

Deputy Director, National Center for Environmental Health/

Agency for Toxic Substances and Disease Registry

Centers for Disease Control and Prevention

\section{Sharunda Buchanan, M.S., Ph.D.}

Director, Division of Emergency and Environmental Health Services

National Center for Environmental Health

Centers for Disease Control and Prevention

\section{Deborah Millette, M.P.H.}

Acting Deputy Director, Division of Emergency and Environmental Health Services

National Center for Environmental Health

Centers for Disease Control and Prevention

\section{Kenneth Rose, M.P.A.}

Associate Director, National Center for Environmental Health/

Agency for Toxic Substances and Disease Registry

Centers for Disease Control and Prevention

\section{Jacquelyn Mason, Ph.D.}

Public Health Analyst

National Center for Environmental Health/

Agency for Toxic Substances and Disease Registry

Centers for Disease Control and Prevention

\section{Susan M. Conrath, Ph.D., M.P.H.}

Captain, United States Public Health Service

Epidemiologist

Indoor Environments Division

U.S. Environmental Protection Agency

\section{Philip Jalbert}

Radon/SIRG Team Leader

Indoor Environments Division

U.S. Environmental Protection Agency

\section{Tom Kelly}

Director, Office of Air and Radiation

Indoor Environments Division

U.S. Environmental Protection Agency 


\section{Maria Doa, Ph.D.}

Director, National Program Chemical Division

U.S. Environmental Protection Agency

\section{Joseph L. Wysocki, Ph.D.}

National Program Leader

Housing and Indoor Environments

Cooperative State Research, Education, and Extension Service

United States Department of Agriculture

\section{Peter Ashley, Dr.P.H.}

Director, Policy and Standards Division

Office of Healthy Homes and Lead Hazard Control

U.S. Department of Housing and Urban Development

\section{Warren Friedman, Ph.D.}

Senior Advisor to the Director

Office of Healthy Homes and Lead Hazard Control

U.S. Department of Housing and Urban Development

\section{Emily Williams}

Interim Director, Programs Division

Office of Healthy Homes and Lead Hazard Control

U.S. Department of Housing and Urban Development

\section{Allen Dearry, Ph.D.}

Interim Associate Director, National Toxicology Program

National Institute of Environmental Health Sciences

National Institutes of Health

\section{ACKNOWLEDGMENTS}

This Call to Action was prepared by the U.S. Department of Health and Human Services/Centers for Disease Control and Prevention/National Center for Environmental Health under the direction of the Office of the Surgeon General. 


\section{Glossary}

Affordable housing: The requirement that the cost of housing, both at initial occupancy and throughout the expected life of the tenancy, is within the financial reach of the target market for such housing, typically lowincome families. An accepted guideline is that housing will cost no more than $30 \%$ of annual income.

Age in place: The ability to continue to live in one's current residence as one ages, rather than going to live with relatives, especially children, or being placed in a nursing home. The ability for residents to "age in place" is largely contingent upon adapting housing to meet the specialized needs of the elderly.

Housing: A structure that serves as a dwelling for one or more persons or families. In this document, housing includes the structure itself, as well as the land and any additional structures within the property-line boundaries. Homes must be of market-competitive quality that can blend in to its neighborhood; this explicitly excludes substandard locations and configurations.

Green building: The practice of reducing building impacts on human health and the environment through better siting, design, construction, operation, maintenance, and removal of building structures and by increasing the efficiency with which buildings and their sites use and harvest energy, water, and materials.

Health literacy: The ability of an individual to access, understand, and use health-related information and services to make appropriate health decisions.

Holistic: Emphasizing the importance of the whole and the interdependence of its parts. From a housing/human health perspective, this entails considering the interactions among the housing structure, occupant behaviors, and health in an integrated manner.

Multifamily dwelling: A building designed to accommodate two or more unrelated households within the same structure. Such structures may require special zoning. Multifamily dwellings include garden apartments, mid-rise and high-rise apartment buildings, and residential condominiums. 
Universal design: An approach to the design and construction of housing and environments to be usable by everyone to the greatest extent possibie regardless of age, ability, or circumstance. Universal design benefits everyone by accommodating everyone, including those with limitations.

Visitability: Construction practices that encourage all homes to offer specific features that make it easier for people-particularly those who develop mobility impairment, the elderly, and persons with disabilities - to live in and visit. A companion to universal design. 

U.S. Department of Health and Human Services

\section{-}

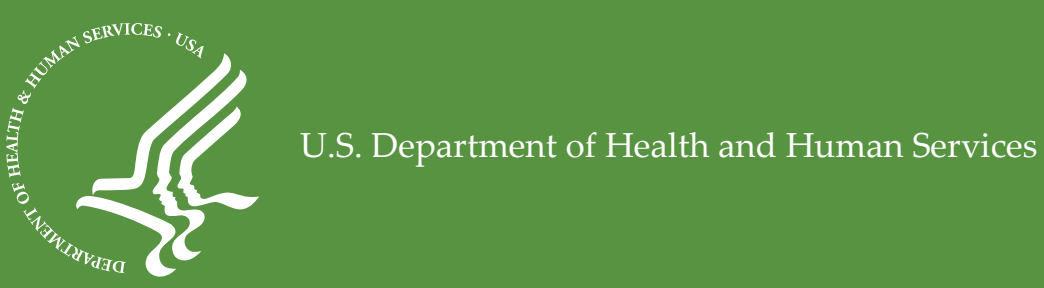

